\title{
Nutrient and mercury deposition and storage in an alpine snowpack of the Sierra Nevada, USA
}

\author{
C. Pearson ${ }^{1,2,3}$, R. Schumer ${ }^{1,3}$, B. D. Trustman ${ }^{2,3}$, K. Rittger ${ }^{4}$, D. W. Johnson ${ }^{3,5}$, and D. Obrist ${ }^{2,3}$ \\ ${ }^{1}$ Division of Hydrologic Sciences, Desert Research Institute, Reno, NV, USA \\ ${ }^{2}$ Division of Atmospheric Sciences, Desert Research Institute, Reno, NV, USA \\ ${ }^{3}$ Graduate Program of Hydrologic Sciences, University of Nevada-Reno, Reno, NV, USA \\ ${ }^{4}$ National Snow and Ice Data Center, Boulder, CO, USA \\ ${ }^{5}$ Department of Natural Resources and Environmental Science, University of Nevada-Reno, Reno, NV, USA
}

Correspondence to: D. Obrist (dobrist@dri.edu)

Received: 29 September 2014 - Published in Biogeosciences Discuss.: 12 January 2015

Revised: 22 April 2015 - Accepted: 30 April 2015 - Published: 16 June 2015

\begin{abstract}
Biweekly snowpack core samples were collected at seven sites along two elevation gradients in the Tahoe Basin during two consecutive snow years to evaluate total wintertime snowpack accumulation of nutrients and pollutants in a high-elevation watershed of the Sierra Nevada. Additional sampling of wet deposition and detailed snow pit profiles were conducted the following year to compare wet deposition to snowpack storage and assess the vertical dynamics of snowpack nitrogen, phosphorus, and mercury. Results show that, on average, organic $\mathrm{N}$ comprised $48 \%$ of all snowpack $\mathrm{N}$, while nitrate $\left(\mathrm{NO}_{3}^{-}-\mathrm{N}\right)$ and TAN (total ammonia nitrogen) made up 25 and $27 \%$, respectively. Snowpack $\mathrm{NO}_{3}^{-}-\mathrm{N}$ concentrations were relatively uniform across sampling sites over the sampling seasons and showed little difference between seasonal wet deposition and integrated snow pit concentrations. These patterns are in agreement with previous studies that identify wet deposition as the dominant source of wintertime $\mathrm{NO}_{3}^{-}-\mathrm{N}$ deposition. However, vertical snow pit profiles showed highly variable concentrations of $\mathrm{NO}_{3}^{-}-\mathrm{N}$ within the snowpack indicative of additional deposition and in-snowpack dynamics. Unlike $\mathrm{NO}_{3}^{-}-\mathrm{N}$, snowpack TAN doubled towards the end of winter, which we attribute to a strong dry deposition component which was particularly pronounced in late winter and spring. Organic N concentrations in the snowpack were highly variable (from 35 to $70 \%$ ) and showed no clear temporal, spatial, or vertical trends throughout the season. Integrated snowpack organic $\mathrm{N}$ concentrations were up to 2.5 times higher than seasonal wet deposition, likely due to microbial immobilization of inorganic
\end{abstract}

$\mathrm{N}$ as evident by coinciding increases in organic $\mathrm{N}$ and decreases in inorganic $\mathrm{N}$ in deeper, aged snow. Spatial and temporal deposition patterns of snowpack $\mathrm{P}$ were consistent with particulate-bound dry deposition inputs and strong impacts from in-basin sources causing up to 6 times greater enrichment at urban locations compared to remote sites. Snowpack $\mathrm{Hg}$ showed little temporal variability and was dominated by particulate-bound forms (78\% on average). Dissolved $\mathrm{Hg}$ concentrations were consistently lower in snowpack than in wet deposition, which we attribute to photochemically driven gaseous re-emission. In agreement with this pattern is a significant positive relationship between snowpack $\mathrm{Hg}$ and elevation, attributed to a combination of increased snow accumulation at higher elevations causing limited light penetration and lower photochemical re-emission losses in deeper, higher-elevation snowpack. Finally, estimates of basin-wide loading based on spatially extrapolated concentrations and a satellite-based snow water equivalent reconstruction model identify snowpack chemical loading from atmospheric deposition as a substantial source of nutrients and pollutants to the Lake Tahoe Basin, accounting for $113 \mathrm{t}$ of $\mathrm{N}, 9.3 \mathrm{t}$ of $\mathrm{P}$, and $1.2 \mathrm{~kg}$ of $\mathrm{Hg}$ each year.

\section{Introduction}

Atmospheric deposition accounts for significant nutrient and pollutant input to high-elevation watersheds such as the Sierra Nevada (Dolislager et al., 2006; Fain et al., 2011; 
McDaniel, 2013; Sickman et al., 2003; TERC, 2011; Vicars and Sickman, 2011; Williams and Melack, 1991a, b). Sierra Nevada snowpack supplies the majority of water to downstream communities as well as to some of the nation's largest agricultural areas. Quantifying atmospheric deposition in alpine watersheds is challenging because of large spatial variability in deposition rates caused by complex terrain, precipitation gradients, and varied origins of atmospheric constituents (i.e., local versus regional and global, natural versus anthropogenic; Jassby et al., 1994; Rohrbough et al., 2003). Single-site measurements, therefore, do not allow for accurate extrapolation of nutrient or pollutant deposition in alpine regions and broader temporal and spatial data are needed to assess the mass and dynamics of atmospheric inputs.

In this study, we used multiple and repeated sampling of full-depth snowpack cores (integrated snowpack sampling) across the Lake Tahoe Basin to quantify atmospheric deposition loads and patterns from the first snowfall until the end of melting. Snowpack acts as an integrating reservoir for water, solutes, and particulates that deposit throughout winter and spring (Turk et al., 2001). Wet deposition, in the form of snowfall and rain, directly accumulates in the developing snowpack throughout the snow season (Kuhn, 2001). Additionally, during storm-free periods, snowpack also receives dry deposition, which is often complicated to quantify since dry deposition samplers can be biased due to different collection efficiencies compared to natural surfaces (Jassby et al., 1994). Representing a natural surface that covers the ground for several months of the year, snowpack sampling thereby can provide accurate on-the-ground measurements of total (bulk: wet and dry) deposition occurring in mountainous areas.

While the snowpack integrates wintertime atmospheric deposition input, it also records chemical and physical transformations that occur during storage such as elution during melt events, chemical transformations, and volatilization. For example, ionic pulses of anions and cations occur upon snowpack melt, whereby ions are thought to be mobilized in the following order: $\mathrm{SO}_{4}^{2-}>\mathrm{NO}_{3}^{-}>\mathrm{Cl}^{-}>$alkali metals $>$alkaline earth metals $>$ cations (other than $\mathrm{NH}_{4}^{+}$) $>$anions $>\mathrm{NH}_{4}^{+}>\mathrm{H}_{2} \mathrm{O}_{2}$ (Berg, 1992; Brooks and Williams, 1999; Kuhn, 2001; Stottlemyer and Rutkowski, 1990; Williams and Melack, 1991b). In addition, pollutants such as $\mathrm{Hg}$ and persistent organic pollutants (POPs) as well as nutrients can undergo photochemical transformations and be subject to substantial gaseous re-emission to the atmosphere (Fain et al., 2011; Halsall, 2004; Lalonde et al., 2002; Poulain et al., 2007). Specific examples include photochemical reduction and re-emission of mercury $(\mathrm{Hg})$ during snowpack storage as well as photolysis and emission of nitrate $\left(\mathrm{NO}_{3}^{-}\right)$from polar snow (Galbavy et al., 2007; Jacobi and Hilker, 2007; Rothlisberger et al., 2002). In addition, microbial activity in and under the seasonal snowpack can play an important role in snowpack $\mathrm{N}$ dynamics (Brooks et al., 1996; Williams et al., 1996), even in Arctic environments with low temperatures and minimal water content (Larose et al., 2013). Therefore, snowpack sampling yields relevant temporal atmospheric deposition patterns in conjunction with post-depositional chemical losses or conversions.

Spatially, snowpack sampling can be an elegant tool to quantify gradients in atmospheric deposition that are difficult to assess with other methods; for example, the Sierra Nevada show strong orographic precipitation effects, with the leeward side receiving significantly less precipitation than the windward side (O'Hara et al., 2009). Such different precipitation patterns can cause large differences in wet deposition across mountain ranges (Fain et al., 2011; NADP, 2012). Assessing spatial deposition patterns using snowpack sampling at multiple locations across a watershed should allow for better characterization of basin-wide deposition patterns as well as assessment of impacts of nearby urban areas versus regional and global sources of atmospheric deposition (Brown et al., 2011; Kuhn, 2001; Morales-Baquero et al., 2006; Vicars and Sickman, 2011).

The main goal of this study was to quantify $\mathrm{N}, \mathrm{P}$, and $\mathrm{Hg}$ concentrations and loads in Sierra Nevada snowpack in order to characterize the magnitude, origin, and fate of atmospheric deposition of nutrients and pollutants that accumulate throughout the winter and spring in this mountain range. We quantified chemical loading at seven sites in the Lake Tahoe Basin, along two elevation transects, throughout the duration of two full snow seasons. Sampling included biweekly snowpack cores (full profile; integrated snowpack samples) representing an integrated load of constituents in the developing snowpack collected throughout the 2011-2012 and 20122013 snow years. In addition, volume-weighted wet deposition measured at two sites in 2013-2014 was compared to snowpack accumulation and detailed vertical snow pit profiles in that year to compare snowpack accumulation to wet deposition and to further study in-snowpack chemical dynamics. Finally, basin-wide loading estimates (mass area ${ }^{-1}$ ) were calculated by spatially extrapolating nutrient and pollutant measurements across the basin combined with a satellitebased snowpack reconstruction model.

\section{Materials and methods}

\subsection{Study Site}

The Lake Tahoe watershed lies in the northern portion of the Sierra Nevada range along the border of Nevada and California. Renowned for its intense blue color and water clarity, this lake has become a national landmark and tourism hotspot. Lake clarity measurements have decreased, however, from approximately 30.5 to $21.3 \mathrm{~m}$ since the 1960 s due to eutrophication from increased input of $\mathrm{N}$ and $\mathrm{P}$, as well as ad- 
ditional input of light-scattering particulates (TERC, 2011). Directly west and upwind of the basin lies the central valley of California and cities of Sacramento and San Francisco, CA, which are believed to contribute significant amounts of nutrients and pollutants to the basin through agricultural and industrial emissions.

Including all drainages, the Lake Tahoe watershed has an area of $1310 \mathrm{~km}^{2}$ (Fig. 1). The lake is $19 \mathrm{~km}$ wide and $35 \mathrm{~km}$ long with a total surface area of $495 \mathrm{~km}^{2}$. The lake lies at $1897 \mathrm{~m}$ above sea level and is on average $300 \mathrm{~m}$ deep. Surrounding the lake on all sides are mountains up to elevations of $3068 \mathrm{~m}$. At the lake's surface, summer temperatures reach on average $27^{\circ} \mathrm{C}$ and wintertime lows reach $-9{ }^{\circ} \mathrm{C}$. Precipitation patterns in the watershed are highly dependent on elevation with an average annual precipitation of $0.76 \mathrm{~m}$ at lake level and an average of $2.03 \mathrm{~m}$ falling at higher elevations in the surrounding mountains (Fram and Belitz, 2011). Extreme snow events in this area are common and often produce snowpack depths greater than $4.5 \mathrm{~m}$ at high elevations. Rain shadow effects typically lead to decreased snow loading on the downwind, eastern side of the basin. Approximately two-thirds of Lake Tahoe Basin parent material is granitic and one-third is volcanic (LTTMDL, 2008). Vegetation, consisting of mixed coniferous forest and montane-subalpine species, cover approximately $80 \%$ of the basin (LTTMDL, 2010). Areas of dense urban development occur along the shoreline at South Lake Tahoe, Tahoe City, and Incline Village. Large portions of the northern and western shores are occupied by seasonal cabins, while much of the eastern shore is undeveloped.

\subsection{Sample collection}

\subsubsection{Integrated snowpack sampling: 2011-2012 and 2012-2013 snow years}

During the 2011-2012 and 2012-2013 water years, fullsnowpack biweekly core samples were collected at seven sites in the basin starting from the first measurable snowpack until the majority of spring melting occurred (2011-2012: $n=49$; 2012-2013: $n=56$ ). This included mid-January through mid-April in 2012 and December to early April in 2012-2013. The seven sites were distributed along eastern and western elevation transects (Fig. 1). Three of the sites were located at lake level (one remote site, two sites in urban areas, elevation approximately $1900 \mathrm{~m}$ ), two sites were at mid-mountain elevation (approximately $2200 \mathrm{~m}$ ), and two sites were at high elevation close to the mountain ridges (elevation approximately $2500 \mathrm{~m}$ ). To minimize throughfall signals, we selected areas that were free of canopy coverage and had minimal snowpack disturbance (i.e., away from congested areas). Canopy effects on total snow accumulation are incorporated in the snow water equivalent (SWE) reconstruction model. However, measurements of deposition and chem-

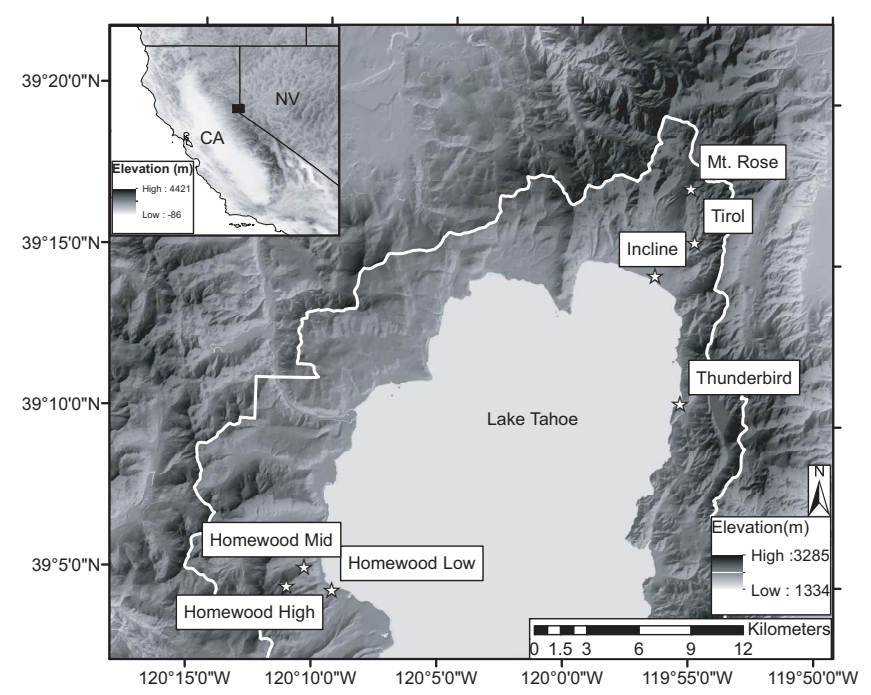

Figure 1. Lake Tahoe watershed map with biweekly sampling sites located along east and west basin elevation gradients for spatial and temporal sampling campaigns in 2011-2012 and 2012-2013. Additional wet deposition and snow pit profile samples were collected near the Homewood High and Mt. Rose sites during the 2013-2014 snow year.

ical snowpack storage are based on canopy-free, open locations, and do not include effects of forest cover.

Samples were collected using a Mt. Rose Federal sampler and were immediately transferred to Whirl-Pak ${ }^{\circledR}$ clean bags and a cooler with blue ice packs. Samples were transported within four hours to the Desert Research Institute in Reno, $\mathrm{NV}$, for storage at $-20^{\circ} \mathrm{C}$ until laboratory analysis could be completed. Depth and SWE were measured for each core using the Mt. Rose Federal sampler. In cases of low snow accumulation, multiple cores were collected and homogenized to provide sufficient sample for all analyses. During collection, sterile gloves were worn, and soil contact and contamination were avoided in order to capture only constituents stored within the snowpack. While sampling, the first core taken at each site was discarded in order to avoid carryover from previous sampling. Between each sampling campaign, the Federal sampler was cleaned with Milli-Q deionized water $(<18.2 \mathrm{M} \Omega)$ and a chelating soap in accordance with trace metal sampling procedures (EPA, 2002). Field blanks were measured by rinsing the sampler with Milli-Q water prior to each sampling campaign.

\subsubsection{Wet deposition sampling and snow pit collection: 2013-2014 snow year}

In order to differentiate between snowpack storage and wet deposition and further assess dynamics in the snowpack, additional sampling of full snow pit profiles and wet deposition was completed during the 2013-2014 snow year. Biweekly wet deposition sample collection following National Atmo- 
spheric Deposition Program protocol (http://nadp.sws.uiuc. edu/) was conducted at the two high-altitude sites by N-Con dual port trace metal samplers (model TM 00-127; N-Con Inc., Crawford, GA, USA). These samplers allowed for collection of real-time wet deposition samples of both nutrients $(\mathrm{N}, \mathrm{P}$, and $\mathrm{S}$ ) and $\mathrm{Hg}$ without cross contamination. The sample trains consist of an NADP standard (19-128) glass funnel, a glass anti-evaporation capillary, a glass sample bottle (2 L) for collection of $\mathrm{Hg}$, and a (19-130) polyethylene funnel with connector and 1.5 L HDPE sample container for nutrients. The glass sample bottle was pre-charged with $20 \mathrm{~mL}$ of deionized water and $0.5 \mathrm{~mL}$ of $12 \mathrm{M} \mathrm{HCl}$ (EMD Omnitrace HX0607) to act as a preservative for $\mathrm{Hg}$. Sample bottles were collected in the field and kept in a cooler during transport back to the Desert Research Institute in Reno, NV. Sample bottles were then weighed in the lab and decanted into $250 \mathrm{~mL}$ HDPE bottles for nutrient samples and glass containers for $\mathrm{Hg}$ samples. All samples were stored in refrigerators until processing.

Three snow pit analyses were conducted at the highelevation sites, two near the Mt. Rose site (1 March and 4 April 2014) and one at the Homewood High site (28 February 2014). The snow pit measured a minimum of a $1.5 \mathrm{~m}^{2}$ and was dug from the snow surface to the ground. Measuring sticks were placed on either side of the pit face. A measurement of height, layer density, and crystal form was noted. Snow samples were collected vertically every $10 \mathrm{~cm}$ using a $1000 \mathrm{~cm}^{3}$ Kelly wedge cutter (model: RIP 1 Cutter; Snowmetrics, Fort Collins, CO, USA). Prior to collection, the acid-washed wedge was inserted into the snow adjacent to the sample wall two to three times at each layer before sampling to avoid carry over. Duplicate samples were collected at each height and analyzed separately. All samples were double-bagged in Whirl-Pak clean bags and weighed for density. Samples were then transferred to $-20^{\circ} \mathrm{C}$ storage at the Desert Research Institute in Reno, NV, until analysis. Reported concentrations and densities are averages of the duplicate samples.

\subsection{Laboratory analysis}

Samples were analyzed for nitrite $\left(\mathrm{NO}_{2}^{-}-\mathrm{N}\right)$, nitrate $\left(\mathrm{NO}_{3}^{-}\right.$$\mathrm{N}$ ), total ammonia nitrogen (TAN; $\mathrm{NH}_{3}+\mathrm{NH}_{4}^{+}$), total Kjeldahl nitrogen $(\mathrm{TKN})$, orthophosphate $\left(\mathrm{o}-\mathrm{PO}_{4}\right)$, total phosphorus (TP), total $\mathrm{Hg}$ (THg, no filtration), and dissolved $\mathrm{Hg}$ (DHg, filtration). Prior to analysis, all samples were removed from the freezer and placed in a dark cabinet at room temperature for approximately $18 \mathrm{~h}$ to melt. Once fully melted, the samples were thoroughly mixed and dispensed into various aliquots for each analysis. Subsamples of $\mathrm{NO}_{2}^{-}-\mathrm{N}, \mathrm{NO}_{3}^{-}-\mathrm{N}$, TAN, $\mathrm{SO}_{4}^{2-}$, and o- $\mathrm{PO}_{4}$ were filtered through $0.45 \mu \mathrm{m}$ filters (Pall Supor ${ }^{\circledR}$ ) prior to analysis. Laboratory filter blanks were approximately $<2 \mu \mathrm{g} \mathrm{L}^{-1}$ for $\mathrm{NO}_{2}^{-}-\mathrm{N}, 6 \mu \mathrm{gL}^{-1}$ for $\mathrm{NO}_{3}^{-}-\mathrm{N}$,
$5 \mu \mathrm{gL}^{-1}$ for TAN, $<20 \mu \mathrm{gL}^{-1}$ for $\mathrm{SO}_{4}^{2-}$, and $2 \mu \mathrm{gL}^{-1}$ for o- $-\mathrm{PO}_{4}$.

Orthophosphate and TP were measured according to EPA Standard Method (SM) 365.1 and SM 365.1/USGS I-460085, respectively (EPA, 1993; USGS, 1985). Method detection limits (MDLs) for these techniques were 0.60 and $0.63 \mu \mathrm{g} \mathrm{L}^{-1}$, respectively. Both techniques employed colorimetric measurement with ascorbic acid. Prior to measurement of TP, samples were digested with persulfate. Absorbance was then measured through flow injection analysis (FIA; Rapid Flow Analyzer 300 equipped with an AstoriaPacific 305D high-sensitivity photometer detector; Alpkem, College Station, TX).

Nitrite, $\mathrm{NO}_{3}^{-}-\mathrm{N}$, and TAN analyses followed EPA SM 353.2 and SM 353.1 (EPA, 1979, 1993). Nitrite and $\mathrm{NO}_{3}^{-}-\mathrm{N}$ MDLs were $0.84 \mu \mathrm{gL}^{-1}$, and the TAN MDL was $0.77 \mu \mathrm{gL}^{-1}$. Nitrite and $\mathrm{NO}_{3}^{-}-\mathrm{N}$ were measured by automated colorimetric analysis with cadmium reduction being applied for the nitrate samples. Each sample was then measured by FIA (Rapid Flow Analyzer 300 equipped with an Astoria-Pacific 305D high-sensitivity photometer detector; Alpkem, College Station, TX). TAN samples were analyzed using automated phenate colorimetric techniques. Total Kjeldahl nitrogen was analyzed using automated phenate block digestion according to EPA SM 351.2. The MDL for TKN was $11.3 \mu \mathrm{gL}^{-1}$. Organic $\mathrm{N}$ (bulk) was calculated as the difference between TKN and TAN. All nitrogen species were reported as $\left[\mu \mathrm{g} \mathrm{L}^{-1}\right]-\mathrm{N}$ with total $\mathrm{N}$ calculated as the sum of organic $\mathrm{N}$, TAN, and $\mathrm{NO}_{3}^{-}-\mathrm{N}$. All snow sample $\mathrm{NO}_{2}^{-}$concentrations were below the detection limit (DL).

Sulfate was determined using a chromatography system (ICS 2000 with Chromeleon version 6.6 software and AS14A column; Dionex Inc., Sunnyville, CA) by EPA SM 300.0 (EPA, 1979). The MDL for $\mathrm{SO}_{4}^{2-}$ was $19 \mu \mathrm{g} \mathrm{L}-1$.

Total $\mathrm{Hg}$ and $\mathrm{DHg}$ were measured using a water analyzer (model 2600; Tekran Inc., Toronto, Canada) according to EPA SM 1631 revision E (EPA, 2002). For DHg samples, approximately $50 \mathrm{~mL}$ of sample was filtered through a $0.45 \mu \mathrm{m}$ filter (Acrodisc syringe filter with Supor ${ }^{\circledR}$ Membrane; Pall Corporation, Port Washington, NY), while for $\mathrm{THg}, 50 \mathrm{~mL}$ of sample was poured directly into a vial for analysis. Laboratory filter blanks were below the DL of the system $\left(<0.3 \mathrm{ngL}^{-1}\right)$. Samples were preserved with $10 \%$ bromine chloride $(\mathrm{BrCl})$ solution for storage until analysis the next day. Before analysis, excess $\mathrm{BrCl}$ was neutralized with pre-purified hydroxylamine hydrochloride. During analysis, samples were automatically mixed with stannous chloride $\left(\mathrm{SnCl}_{2}\right)$ in a phase separator; reducing oxidized $\mathrm{Hg}$ to elemental $\mathrm{Hg}$. Elemental $\mathrm{Hg}$ is then loaded onto two sequential gold traps by an argon carrier gas. The $\mathrm{Hg}$ is then released through thermal desorption and detected using atomic fluorescence spectrometry. The Tekran model 2600 was calibrated using a NIST SRM-3133 Hg standard (with concentrations of $0,0.5,1.0,5.0,10.0,25.0$, and $50.0 \mathrm{ng} \mathrm{L}^{-1} \mathrm{Hg}$ ). 
System reliability was checked using ongoing precision recovery injections of $5 \mathrm{n} \mathrm{L}^{-1}$ throughout each run and ranged between 87 and $112 \%$ recovery. Reagent blanks measured regularly throughout each run ensured no contamination of the system. DLs calculated as 3 times the standard deviation of the calibration blanks, averaged $0.3 \mathrm{ng} \mathrm{L}^{-1}$ for all runs. Particulate $\mathrm{Hg}$ was calculated as the difference between $\mathrm{THg}$ and DHg.

\subsection{Statistics}

We performed analysis of variance (ANOVA) for all chemical species using the following independent variables: (i) year ( $n=2,2011-2012$ and 2012-2013), (ii) site elevation ( $n=3$; low-, mid- and high-elevation site), (iii) location ( $n=2$; eastern and western basin), and season ( $n=2$; early season (December through February) and late season (March and April)). ANOVAs attribute variance of dependent variables to these various independent variables and test their significance against the residual variance. All relationships were considered statistically significant when $p$ values were $\leq 0.05$.

Integrated snowpack concentrations were calculated by weighting each $10 \mathrm{~cm}$ snow pit layer by its density. Seasonal wet deposition was calculated by weighting all wet deposition samples by their volume up to the date of sampling. Linear regression analyses were performed to test for correlations between snowpack chemical concentrations, SWE, and elevation. All error bars in figures represent standard error.

\subsection{Basin-wide modeling with SWE reconstruction}

Basin-wide loads and distribution were assessed using chemical concentrations and loads measured throughout the 20112012 and 2012-2013 snow seasons as well as basin-wide mean peak SWE estimates from SWE reconstruction for the Sierra Nevada from 2000 to 2011 (Rittger, 2012). SWE reconstruction uses estimates of snow energy balance with areal snow cover depletion from MODIS Snow Covered Area and Grain size (MODSCAG) (Rittger et al., 2011). MODSCAG calculates fractional snow cover area and grain size from MODIS data (Painter et al., 2009). Compared with previous methods, MODSCAG has proven to give reliable depletion rates throughout the spring season, when snowmelt is highest (Rittger et al., 2013). Finally, the spatially refined MODSCAG data set was combined with energy balance and temperature data to give accurate reconstructed estimates of SWE throughout the Sierra Nevada, and specifically the Lake Tahoe Basin. At the time of our study, SWE reconstruction data were only available for 2000 to 2011, with no information from our sampling seasons, 2011-2012 or 20122013. The 2000-2011 data set includes both high- and lowaccumulation snow years and gives a reasonable representation of average snowpack accumulation in the Lake Tahoe Basin. In order to give an estimate of average annual snow-
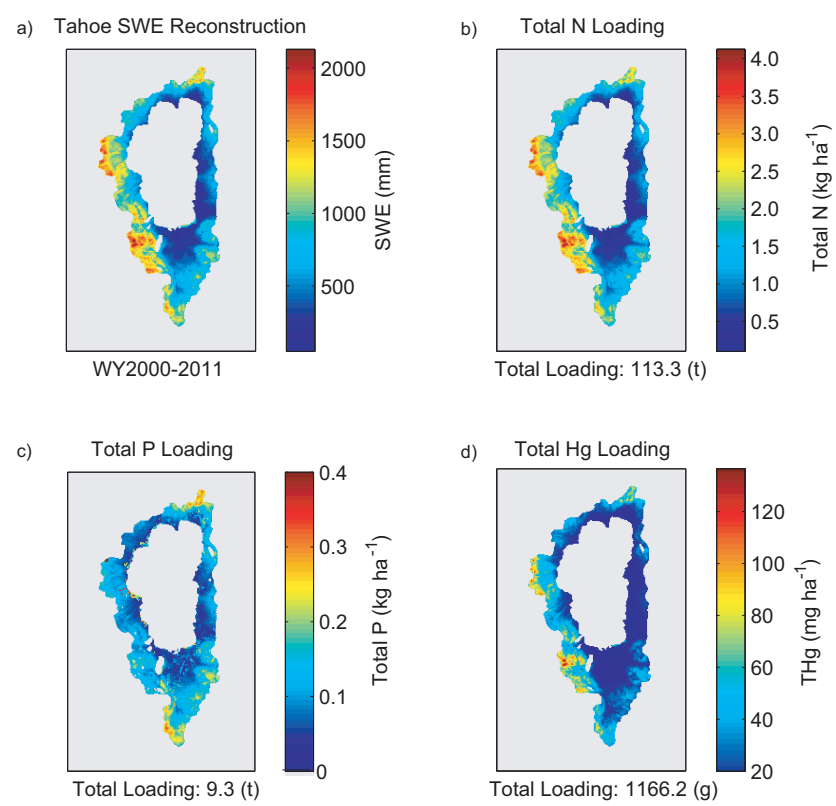

Figure 2. (a) Decadal average (2000-2011) peak SWE for the Tahoe Basin from SWE reconstruction for the Sierra Nevada, and basin-wide peak snowpack chemical loading estimates for (b) nitrogen, (c) total phosphorus, and (d) total $\mathrm{Hg}$.

pack chemical storage, we applied the decadal average peak SWE for 2000-2011 to our data (Fig. 2a). Estimates made during this study were to establish relationships to previous estimates of the Lake Tahoe nutrient budget and were not meant to represent a completely accurate distribution or load stored within the basin's snowpack each year.

Snowpack sampling throughout the Lake Tahoe Basin during 2011-2012 and 2012-2013 allowed for assessment of spatial and temporal chemical deposition patterns. Specifically, relationships to wet or dry deposition, in-basin or outof-basin sources, and early- or late-season increases were identified. These deposition and source controls were then related to orographic characteristics to estimate chemical concentrations throughout the basin in unknown areas. A GIS land-use layer of the Tahoe Basin (LTTMDL, 2010) was applied in order to separate urban and non-urban locations with similar orographic characteristics for urban-influenced species (i.e., TP). These scaled concentrations were then applied to SWE reconstruction estimates to determine total snowpack chemical loading throughout the entire basin.

Snowpack sampling occurred in open areas free of canopy coverage, but it is possible that tree and plant particulate matter was still incorporated in the snowpack. Litterfall contributions represent a form of chemical recycling and will cause an overestimate of atmospheric contributions made during this study. Visual inspection of snow samples, however, showed low contributions of plant detritus in samples, and due to consistent forest types present across the basin we 
would expect any additional plant-derived inputs to be random and unbiased across sites.

\section{Results and discussion}

\subsection{Spatial and temporal trends of snow accumulation and SWE}

In the Lake Tahoe Basin, approximately $70 \%$ of annual precipitation falls during the winter and spring as snow (Fram and Belitz, 2011). The 2011-2012, 2012-2013, and 2013-2014 winter seasons were marked by relatively low snow accumulation. Peak basin average snowpack storage (1 April) for the central Sierra Nevada during 2011-2012, 2012-2013, and 2013-2014 was approximately 50, 53, and $41 \%$ of the historical average (1951-present), respectively (CADWR, 2014). Although peak SWE was similar in each season, the temporal trends in snow accumulation and spatial distributions differed (Fig. 3). In 2011-2012, the Lake Tahoe Basin experienced low snowpack accumulation until the middle of January, when a series of storms led to solid snow cover throughout the basin. January storms were followed by a hiatus until late February and March, when a series of storms brought peak basin average SWE up to approximately $625 \mathrm{~mm}$. The 2012-2013 snow year started earlier, with late December storms bringing nearly $750 \mathrm{~mm}$ of SWE. Similar snowpack loading and timing occurred across the Lake Tahoe Basin at sites with similar elevations (e.g., Mt. Rose/Squaw Valley, Marlette Lake/Rubicon). Early season storms were dominated by northerly wind patterns contributing substantial snowfall in the northeastern areas of the Lake Tahoe Basin and reducing the typical pattern of lower snow accumulation on the eastern side of the basin due to the rain shadow effect of the Sierra Nevada crest (e.g., 2012-2013 Mt. Rose/Squaw Valley SNOTEL data). These early storms were followed by three dry months with very little accumulation for the rest of winter. The 2013-2014 snow year experienced the lowest snow accumulation of all three study years, with minimal snowpack development occurring until lateseason storms in March and April brought peak SWE storage up to approximately $575 \mathrm{~mm}$. Minimal snowpack development occurred at lower lake level elevations (e.g., Tahoe City SNOTEL data) throughout the entire 2013-2014 season.

\subsection{Nitrogen}

\subsubsection{Nitrate $\left(\mathrm{NO}_{3}-\mathrm{N}\right)$}

Snowpack $\mathrm{NO}_{3}^{-}-\mathrm{N}$ concentrations ranged from 20 to $138 \mu \mathrm{gL}^{-1}$ ( $n=49$ cores), 14 to $98 \mu \mathrm{g} \mathrm{L}{ }^{-1}$ ( $n=56$ cores), and 28 to $62 \mu \mathrm{gL}^{-1}(n=3$ integrated snow pits) during 2011-2012, 2012-2013, and 2013-2014, respectively. These values were comparable with previous measurements at the Emerald Lake Watershed, a remote watershed in the southern Sierra Nevada (Williams et al., 1995). During 2011-

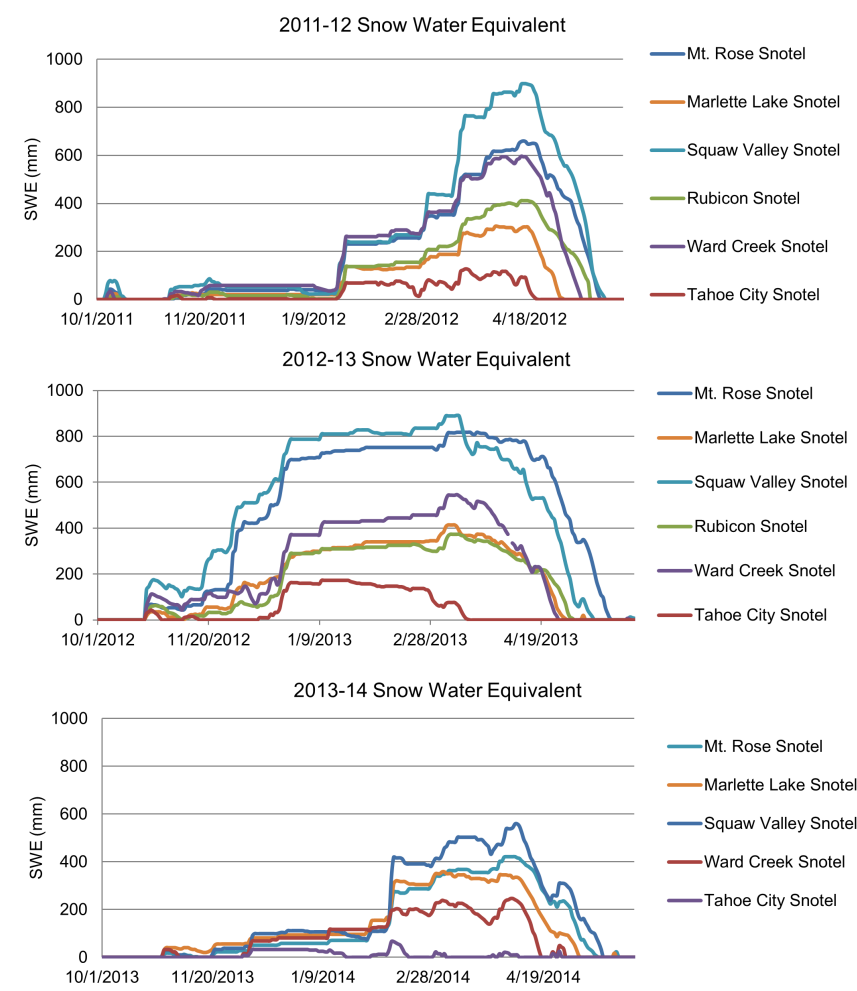

Figure 3. Snow water equivalent measured in 2011-2012, 20122013, and 2013-2014 at select SNOTEL sites (NRCS, 2013) throughout the Lake Tahoe Basin.

2012 and 2012-2013 (i.e., the 2 years with detailed spatial and temporal sampling), no distinguishable temporal or spatial pattern was observed in either snowpack $\mathrm{NO}_{3}^{-}-\mathrm{N}$ concentrations or loads (Fig. 4). ANOVA results confirmed that snowpack $\mathrm{NO}_{3}^{-}-\mathrm{N}$ concentrations were not statistically affected by elevation, location (i.e., east/west), or early- versus late-season sampling (Table 1). Comparisons of wet deposition and integrated average snow pit concentrations during the 2013-2014 snow year showed that snowpack $\mathrm{NO}_{3}^{-}-\mathrm{N}$ concentrations were similar to volume-weighted wet deposition up to the date of snowpack sampling (Fig. 5). This result is similar to patterns observed by Clow et al. (2002) and Williams and Melack (1991a) and may be indicative of wet deposition as the main source of $\mathrm{NO}_{3}^{-}-\mathrm{N}$ deposition. For example, wintertime deposition of $\mathrm{NO}_{3}^{-}-\mathrm{N}$ in the Rocky Mountains was found to be highly correlated with precipitation, with little difference between snowpack and NADP precipitation volume-weighted mean concentrations, suggesting mainly wet deposition inputs (Clow et al., 2002). Similarly, a study at the Emerald Lake Watershed identified that dry deposition of $\mathrm{NO}_{3}^{-}$was not an important contributor of total $\mathrm{NO}_{3}^{-}$load in winter snowpack (Williams and Melack, 1991a). Our study revealed that increased precipitation on the west side of the Tahoe Basin during 2011-2012 led to correspondingly greater $\mathrm{NO}_{3}^{-}$loading; however, little differ- 
Table 1. Analysis of variance results for 2011-2012 and 2012-2013 snowpack concentrations. Controlling factors of year ( $n=2 ; 2011-2012$, 2012-2013), elevation ( $n=3$; high, middle, low), location ( $n=2$; east, west), and season ( $n=2$; early, late) were investigated.

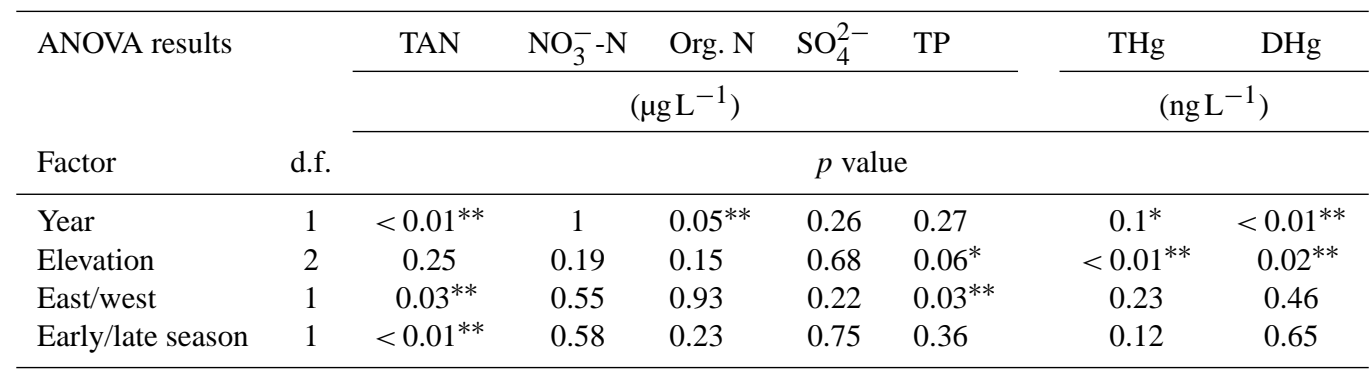

${ }^{*} p$ value $<0.10,{ }^{* *} p$ value $<0.05$.
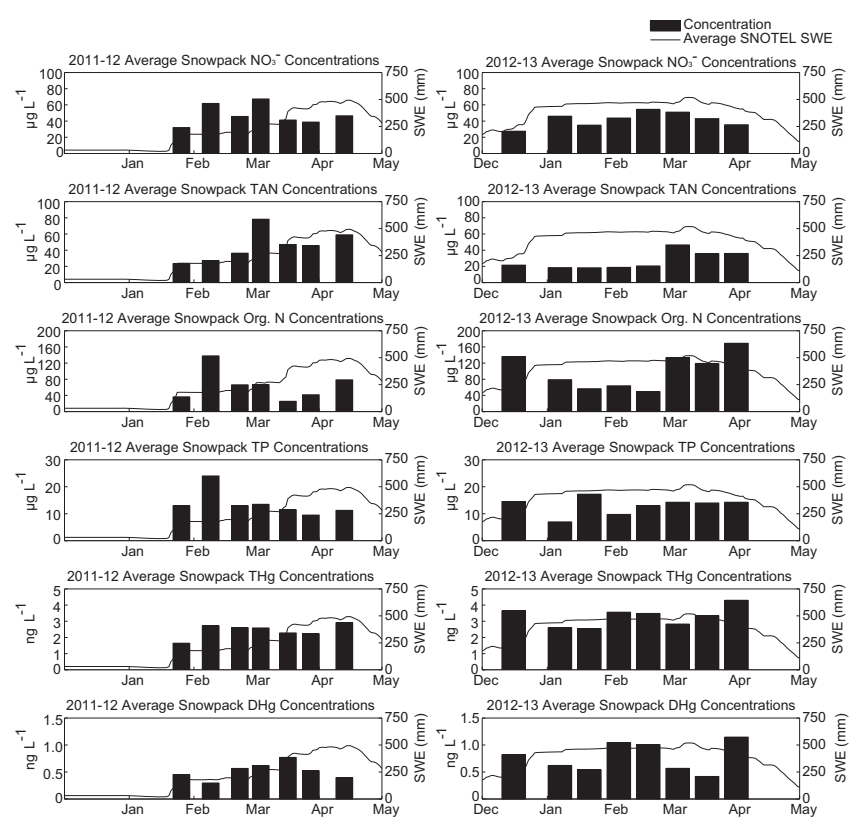

Figure 4. Average snowpack core concentrations during 2011-2012 (left) and 2012-2013 (right) snow seasons along with average SWE estimated from six SNOTEL sites located within the Tahoe Basin.

ence was seen during 2012-2013, when precipitation totals throughout the basin were more uniform.

Vertical snow pit profile patterns show large variability in $\mathrm{NO}_{3}^{-}$-N concentrations with depth, e.g., decreasing concentrations below the top $30-40 \mathrm{~cm}$ (Fig. 6). This variability suggests pronounced in-snowpack dynamics possibly driven by conversion, vertical transport, or elution. In addition, several studies have shown significant wintertime dry deposition of $\mathrm{NO}_{3}^{-}-\mathrm{N}$, in particular close to highways and urban areas (Cape et al., 2004; Dasch and Cadle, 1986; Kirchner et al., 2005). Therefore, the fact that wet deposition concentrations were very similar to snowpack concentrations could be merely a coincidence and may not allow us to infer dry versus wet deposition of $\mathrm{NO}_{3}^{-}-\mathrm{N}$.

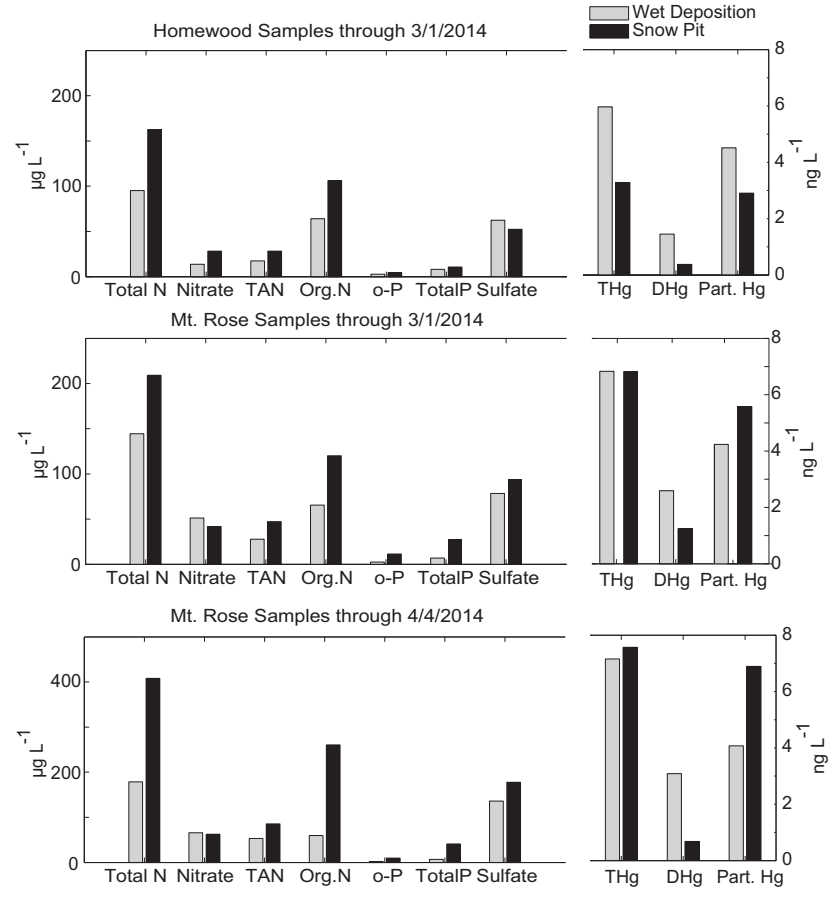

Figure 5. Comparison of seasonal average volume-weighted wet deposition concentrations with integrated snow pit samples from the 2013-2014 snow year.

Previous studies have observed parallel concentration declines of $\mathrm{SO}_{4}^{2-}$ and $\mathrm{NO}_{3}^{-}-\mathrm{N}$ during snowpack melt events due to similar early-season ionic pulses that lead to preferential losses of nutrients and other ions (Bales et al., 1989; Harrington and Bales, 1998; Tranter et al., 1986). In support of such potential losses, Fig. 4 shows decreasing snowpack $\mathrm{NO}_{3}^{-}$concentrations in spring months, particularly in the second year, 2012-2013, when sampling captured the beginning of the melt season. Preferential mobilization of solutes during melt events has also been shown to cause downward movement of solutes in the snowpack (Williams and Melack, 1991b). Our vertical snow pit samples show highly variable distribution patterns with depth (Fig. 6), which may indi- 

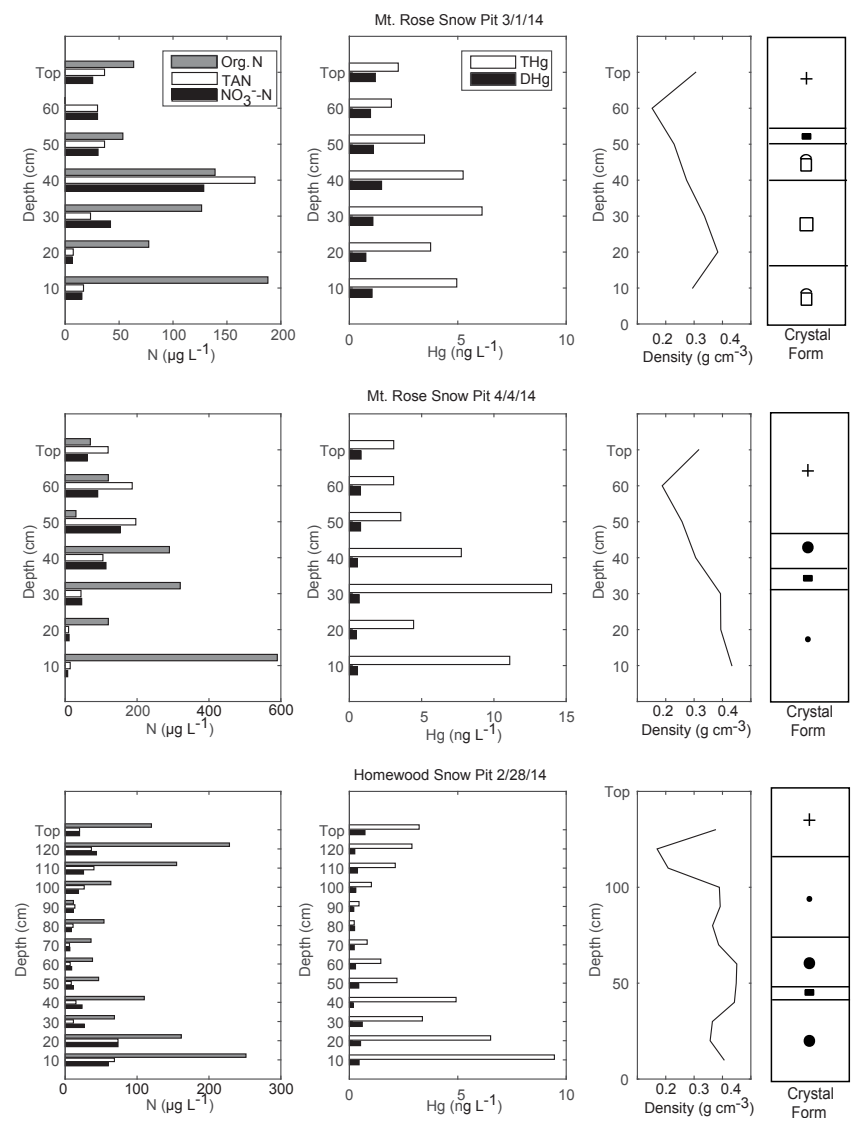

Figure 6. Year 2013-2014 snow pit profiles for nitrogen and mercury species concentrations, snow density, and crystal form. Crystal classifications are based on the ICSI classification for seasonal snow on the ground (Fierz et al., 2009).

cate insufficient temporal resolution of pit sampling to detect vertical translocation. Similar early elution characteristics have been observed for $\mathrm{NO}_{3}^{-}$and $\mathrm{SO}_{4}^{2-}$ (Stottlemyer and Rutkowski, 1990; Williams and Melack, 1991b), and comparing volume-weighted seasonal wet deposition concentrations of $\mathrm{SO}_{4}^{2-}$ and snowpack $\mathrm{SO}^{2-}$ concentrations showed no large elution losses either (Fig. 5). Our results suggest that Tahoe Basin snowpack $\mathrm{NO}_{3}^{-}$is subject to multiple inputs and complex in-snowpack processes, and that potential losses (such as during early ionic pulses) may be difficult to detect against additional surface (e.g., dry) deposition processes without very detailed time- and depth-resolved snowpack measurements.

\subsubsection{Total ammonia nitrogen (TAN)}

Snowpack concentrations of TAN ranged from 16 to $104 \mu \mathrm{gL}^{-1}$ ( $n=49$ cores), 10 to $77 \mu \mathrm{gL}^{-1}$ ( $n=56$ cores), and 28 to $85 \mu \mathrm{gL}^{-1} \quad(n=3$ integrated snow pits $)$ during 2011-2012, 2012-2013, and 2013-2014, respectively. Snowpack TAN concentrations are within the range of previous measurements made in the Emerald Lake Watershed of
California, where the amount of TAN deposited within the seasonal snowpack accounted for approximately $90 \%$ of annual loading (Williams et al., 1995).

Unlike $\mathrm{NO}_{3}^{-}-\mathrm{N}$, TAN is known to deposit through both wet and dry pathways during winter (Clow et al., 2002; Ingersoll et al., 2008). In our study, strong evidence for an important role of TAN dry deposition can be inferred from the fact that snowpack TAN concentrations doubled from the early (December-February) to the late (March-April) season in both 2011-2012 and 2012-2013 (Fig. 4). ANOVA results confirmed significant differences in snowpack TAN concentrations between early- and late-season snowpack sampling (Table $1, p=0.01$ ). Increased late-season TAN concentration in snowpack is consistent with similar observations in the Rocky Mountains and the Stubai Alps (Bowman, 1992; Kuhn, 2001). These increases were attributed to the onset of agricultural production in upwind valleys, as well as increased dry deposition due to decreased atmospheric stability and increased convection. Importantly, the late-season increase in snowpack TAN occurred in both years, even though no significant late-season snowfall occurred in 2012-2013 (Fig. 4). The patterns of increasing TAN concentration in late-season snowpack with no significant snowfall agree with previous research showing dry deposition as the significant source of TAN deposition in the Sierra Nevada (Bytnerowicz and Fenn, 1996).

Large increases in $\mathrm{NH}_{3}$ emissions from winter to spring have been measured upwind of the Sierra Nevada in the San Joaquin Valley, CA, and were attributed to increased agricultural and livestock activities (Battye et al., 2003). Further support of snowpack TAN sourcing in the San Joaquin Valley was higher concentrations at west basin sites than east basin sites during both 2011-2012 and 2012-2013. ANOVA results revealed a significant difference between the east and west basin snowpack TAN concentrations (Table 1, $p=0.03$ ). This increase is likely due to the west basin sites being closer in proximity to San Joaquin Valley agricultural activity, allowing for increased transport and deposition.

During the 2013-2014 snow year, TAN concentrations were consistently higher (up to a factor of 1.7) in integrated snow pit samples than in volume-weighted wet deposition (Fig. 5; $p=0.08$; note low replicate of $n=3$ ). This increase in TAN further emphasizes the importance of dry deposition of TAN to Tahoe Basin snowpack. During snowpack storage, TAN is known to elute relatively late during melt events (Kuhn, 2001); however, other transformations such as microbial conversion can lead to decreases and losses throughout the season. Snow pit depth profile sampling shows a decrease in TAN concentrations with depth and therefore age (Fig. 6). This decrease coincides with increases in organic $\mathrm{N}$ suggesting microbial conversion of inorganic $\mathrm{N}$ to organic $\mathrm{N}$. Despite these possible losses, the increase we observe between wet deposition and snow pit concentrations indicates that the additional input of TAN from dry deposition is large enough 
to exceed transformations that occur during snowpack storage.

Late season deposition doubled TAN snowpack loads prior to end-of-season melt. The fate of snowpack TAN has been studied extensively through both watershed mass balance and tracer-based research. For example, less than $1 \%$ of TAN stored in snowpack at Emerald Lake, CA, reached the lake as TAN during melt and runoff (Williams and Melack, 1991b). During a later study, however, snowmelt with isotopically labeled $\mathrm{NH}_{3}$ was retained in the soils during melt, making it a possible contributor to future $\mathrm{NO}_{3}^{-}$stream pulses after nitrification (Williams et al., 1996). Current predictions show an increase in total $\mathrm{N}$ emissions during the next half-century in the western United States due to large increases in agricultural and livestock $\mathrm{NH}_{3}$ emissions (Fenn et al., 2003). Such increased emissions could result in significant additional deposition loads of TAN to snowpack in the Sierra Nevada with the potential to alter ecosystem nutrient dynamics.

\subsubsection{Organic nitrogen}

Integrated snowpack organic $\mathrm{N}$ concentrations ranged from BDL (below detection limit) to $211 \mu \mathrm{g} \mathrm{L}^{-1}$ in $2011-2012$ ( $n=49$ cores), BDL to $253 \mu \mathrm{gL}^{-1}$ in 2012-2013 $(n=$ 56 cores), and 120 to $260 \mu \mathrm{gL}^{-1}$ in $2013-2014$ ( $n=3$ integrated snow pit). No dominant spatial or temporal patterns were observed in snowpack organic $\mathrm{N}$ concentrations or loads for either 2011-2012 or 2012-2013 (Fig. 4). ANOVA results supported this finding with no significant effects of location, elevation, or early/late season on organic $\mathrm{N}$ concentrations (Table 1). A previous study found large variation in wintertime deposition of organic $\mathrm{N}$ throughout the Rocky Mountain Range, accounting for 40, 3, and $50 \%$ of total $\mathrm{N}$ in wet deposition during January, February, and March, respectively (Benedict et al., 2013). Deposition rates and patterns of organic $\mathrm{N}$ are difficult to quantify due to the large number of compounds - including gaseous, particulate, and dissolved phases - originating from local, regional, and global sources and subject to biological and chemical transformations (Cape et al., 2011; Neff et al., 2002).

Overall, snowpack core samples collected during the 2011-2012 and 2012-2013 seasons showed high fractions of organic $\mathrm{N}$, accounting for $49 \pm 17 \%$ of total snowpack $\mathrm{N}$ on average. Inorganic forms, TAN and $\mathrm{NO}_{3}^{-}-\mathrm{N}$, accounted for $21 \pm 10$ and $29 \pm 10 \%$, respectively (Fig. 7). Research at a high-elevation catchment in the Colorado Front Range identified organic $\mathrm{N}$ as an important component in both wintertime wet deposition and stream export (Williams et al., 2001), while data from a 14-year study (WY1985-1998) in the Southern Sierra Nevada report that dissolved organic nitrogen (DON) accounted on average for $35 \%$ of total $\mathrm{N}$ $\left(\mathrm{NH}_{4}^{+}+\mathrm{NO}_{3}^{-}+\mathrm{DON}\right)$ in winter precipitation (Sickman et al., 2001). Comparison of volume-weighted wet deposition and integrated snow pit concentrations showed higher concentrations (up to a factor of 2.5) of organic $\mathrm{N}$ in the snow-
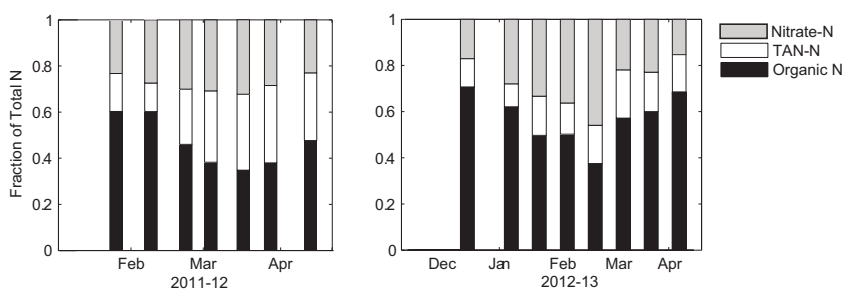

Figure 7. Snowpack total N distribution for 2011-2012 (left) and 2012-2013 (right).

pack (Fig. 5). Two possible sources could cause higher concentrations of organic $\mathrm{N}$ in snowpack compared to wet deposition: snowpack microbial conversion of inorganic $\mathrm{N}$ to organic $\mathrm{N}$ and dry deposition of organic $\mathrm{N}$ during stormfree periods (Clement et al., 2012; Jones, 1999; Williams et al., 2001). Our measurements do not allow for differentiation between the two possible sources of snowpack organic $\mathrm{N}$; however snow pit profile sampling shows coinciding decreases in inorganic $\mathrm{N}$ and increases in organic $\mathrm{N}$ with snow pit depth and therefore age (Fig. 6). One Arctic snowpack study found that microbially based $\mathrm{N}$ cycling was a dominant process explaining $\mathrm{N}$ species availability at the base of the snowpack (Larose et al., 2013). We suggest that microbial uptake of inorganic $\mathrm{N}$ may be a primary driver of the increasing snowpack organic $\mathrm{N}$ levels during storage. Overall, we observed that the dominant form of $\mathrm{N}$ in Sierra Nevada snowpack during our study was organic $\mathrm{N}$, and we propose that this large representation warrants detailed studies in regard to the sources, cycling, and fate of organic $\mathrm{N}$ in the Sierra Nevada.

Concentrations and loads of total $\mathrm{N}$ in snowpack are apparently dependent on contributions of both inorganic and organic forms, with respective differences in deposition pathways (wet versus dry deposition), potential conversion processes (e.g., from inorganic to organic forms), and different mobilization during elution sequences leading to large fluctuations in both the concentration and spatiotemporal patterns of snowpack total $\mathrm{N}$ throughout the season. Total $\mathrm{N}$ accumulation in Sierra Nevada snowpack shows strong interannual variability as well as different representation of various $\mathrm{N}$ species.

\subsection{Phosphorus}

Snowpack TP concentrations ranged from 3 to $109 \mu \mathrm{g} \mathrm{L}^{-1}$ in 2011-2012 ( $n=49$ cores), 3 to $59 \mu \mathrm{g} \mathrm{L}^{-1}$ in $2012-2013$ ( $n=56$ cores), and 10 to $41 \mu \mathrm{gL}^{-1}$ in $2013-2014$ ( $n=3$ integrated snow pits). Figure 8 shows that the urban site in Incline Village at lake level had by far the highest snowpack TP concentrations, ranging up to 6 times higher than any other snowpack concentration at similar elevation (i.e., lake level). In comparison, the Thunderbird site, also at lake level, located in a very remote setting just $10 \mathrm{~km}$ from In- 


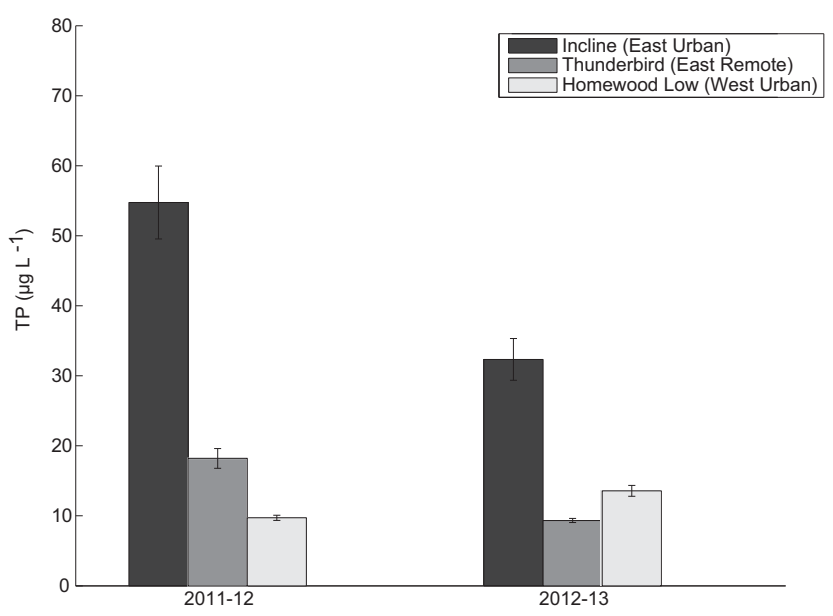

Figure 8. Average snowpack total phosphorus concentrations at all lake-level sites. The Incline and Thunderbird sites are located on the east side of the basin in urban and remote settings, respectively, and the Homewood Low site is located on the west side of the basin in an urban setting.

cline, had much lower P concentrations. Sources such as fugitive dust from plowing, forest and agriculture biomass burning, and diesel engine combustion have been identified as major sources of particulate-phase atmospheric $\mathrm{P}$ in California (Alexis et al., 2001). Specifically, in the Lake Tahoe Basin, road dust has been identified as a primary contributor of P input into Lake Tahoe (Dolislager et al., 2012), while another study found significant $\mathrm{P}$ emissions from urban biomass burning (Zhang et al., 2013). Our patterns suggest that urban areas in the Lake Tahoe Basin are a major source area for P deposition to snowpack during winter and spring.

Local and regional emissions are also relevant at larger scales, as evident in 2011-2012, when remote sites at eastern locations in the basin showed higher TP concentrations than western sites. We propose that the large concentration of urban source sites at lake level combined with the dominant west to east wind pattern led to increased deposition on the east side of the basin. During 2012-2013, no west-toeast increase in TP concentration was observed; however, the strong influence of urban activity remained. It is unlikely that sources of P in the basin changed between 2011 and 2012 and between 2012 and 2013, and it is more likely that different deposition patterns due to differences in snow accumulation, timing, and storm track directions caused this change. Even though there was significantly higher $\mathrm{P}$ deposition on the east side of the basin from urban influence, the relatively remote west basin snowpack still had TP concentrations of $11.8 \mu \mathrm{g} \mathrm{L}-1$ on average. Diffuse regional $\mathrm{P}$ sources to the Tahoe Basin include both dust and aerosol inputs. Particulate matter particles smaller than $10 \mu \mathrm{m}$ in diameter $\left(\mathrm{PM}_{10}\right)$ are capable of long-range transport, while larger particles have higher deposition velocities and decreased transport (Vicars et al., 2010). Specifically, dust-derived inputs originate from geologic sources and erosion from both agricultural and urban activity, while burning from both forest and domestic fires contributes additional particulate matter in the form of ash and soot (Raison et al., 1985). Differences in P deposition rates between the dry and wet seasons as well as spatial patterns associated with wind direction and soil erosion vulnerability have been observed in the southern Sierra Nevada; Ontario, Canada; and the Mediterranean (Brown et al., 2011; Morales-Baquero et al., 2006; Vicars and Sickman, 2011).

Comparison of volume-weighted wet deposition and integrated snow pit concentrations showed higher levels of TP (up to a factor of 5.8) in snowpack than wet deposition (Fig. 5). This increase further supports dry deposition as a primary input of snowpack P. Finally, snowpack o- $-\mathrm{PO}_{4}$, the most bioavailable form of P (Dodds, 2003), accounted for $34 \pm 15 \%$ of snowpack TP, similar to previous work in the Lake Tahoe region that estimated approximately $40 \%$ of TP in atmospheric deposition was in a bioavailable form (LTTMDL, 2010).

Low P levels in parent material make high-elevation watersheds of the Sierra Nevada, sensitive to the effects of external P inputs (Melack and Stoddard, 1991; White et al., 1999). Further research, however, has shown that extractable P levels of parent material strongly influence $\mathrm{P}$ adsorption. The very high extractable $\mathrm{P}$ levels in granitic soils in the Sierra Nevada lead to low $\mathrm{P}$ adsorption potentials, while the low extractable P levels and sesquioxide content of volcanic soils in the Sierra Nevada increase adsorption (Johnson et al., 1997). Approximately two-thirds of the Lake Tahoe Basin parent material is granitic and one-third is volcanic (LTTMDL, 2008), making soil adsorption potentials of atmospherically deposited $\mathrm{P}$ throughout the watershed highly variable with location. Along with N, P levels directly control algal production within aquatic ecosystems, and algal production is a key reason for declining clarity in Lake Tahoe (Dolislager et al., 2006). In particular, the high snowpack concentrations at urban locations near the lake may cause a significant influx of $\mathrm{P}$ into Lake Tahoe during melt.

\subsection{Mercury}

Snowpack $\mathrm{THg}$ concentrations ranged from 0.81 to $7.58 \mathrm{ngL}^{-1}$ in 2011-2012 ( $n=49$ cores $), 0.97$ to $5.96 \mathrm{ngL}^{-1}$ in $2012-2013$ ( $n=56$ cores), and 3.28 to $7.56 \mathrm{ng} \mathrm{L}^{-1}$ in 2013-2014 ( $n=3$ integrated snow pits). The Tahoe Basin average snowpack core THg concentration for 2011-2012 and 2012-2013 was 2.56 $\pm 1.3 \mathrm{ngL}^{-1}$. Observed $\mathrm{THg}$ concentrations are slightly lower, but within range of the end-of-season average snowpack concentration measured during a watershed $\mathrm{Hg}$ balance study in 2009 at Sagehen Creek, CA (i.e., $3.3 \mathrm{ngL}^{-1}$; Fain et al., 2011), a remote watershed located only $32 \mathrm{~km}$ north of the Tahoe Basin. Particulate $\mathrm{Hg}$ was the dominant form of $\mathrm{Hg}$ within Tahoe snowpack, accounting for $76.1 \pm 8.7,70.3 \pm 13.4$, and 
$87.1 \pm 4.7 \%$ of $\mathrm{THg}$ on average during 2011-2012, 20122013, and 2013-2014, respectively. The large percentage of particulate $\mathrm{Hg}$ in the snowpack agrees with previous findings from a study in Canada that saw a post-depositional increase in particulate associated $\mathrm{Hg}$ from approximately 50 to $70 \%$ (Poulain et al., 2007). This study attributed particulate throughfall and photochemically induced emission as the main causes of the speciation shift and also noted strong differences in snowpack $\mathrm{Hg}$ concentrations between open and forested areas which were attributed to throughfall contributions from tree canopies as well as shading reducing photochemical evasion.

Snowpack coring revealed no dominant temporal or spatial patterns in $\mathrm{THg}$ or $\mathrm{DHg}$ deposition, with ANOVA results showing no significant effects of season (i.e., early versus late) or location (i.e., east versus west; Table 1). The lack of spatial trends suggests global background atmospheric pollution, rather than specific point sources such as urban areas, to be the main source of snowpack $\mathrm{Hg}$ in the Lake Tahoe Basin. Mercury's long atmospheric lifetime and global circulation allow for diffuse deposition to this relatively remote mountain region (Fain et al., 2011; Schroeder and Munthe, 1998), and the majority of large snowfall events in the Sierra Nevada originate as large-scale convection cells in the eastern Pacific and travel hundreds of kilometers before reaching the Tahoe Basin (O'Hara et al., 2009). To our knowledge, few point sources for $\mathrm{Hg}$ emission exist within the Lake Tahoe Basin, although one study within the basin reported that significant amounts of particulate $\mathrm{Hg}$ are emitted from wildfires (Zhang et al., 2013) and found increased levels of particulate $\mathrm{Hg}$ in urban areas of the Lake Tahoe Basin.

Both $\mathrm{THg}$ and DHg concentrations in the snowpack significantly increased with elevation in the basin (Table 1; $p<0.05$ ). This finding is in contrast to an expected "washout effect", which causes declines in $\mathrm{Hg}$ precipitation concentrations with storm duration and magnitude (Poissant and Pilote, 1998). King and Simpson (2001) observed that approximately $85 \%$ of photochemical reactions occur in the top $10 \mathrm{~cm}$ of the snowpack. It is possible that the increase in $\mathrm{Hg}$ concentration with elevation is due to decreased light penetration relative to snowpack depth and reduced photochemical re-emission, as increased elevation leads to the formation of a deeper, denser snowpack. In support of this notion is a significant positive correlation between integrated snowpack THg concentration and total SWE (slope: 0.002 $\left[\mathrm{ng} \mathrm{L}{ }^{-1} \mathrm{SWE}(\mathrm{mm})^{-1}\right]$; $p$ value: $\left.<0.05\right)$, as well as strong elevation gradients in total snowpack $\mathrm{Hg}$ pools. In agreement, total snowpack $\mathrm{Hg}$ loading was significantly higher in 2012-2013 than in 2011-2012 (Table 1; $p<0.01$ ) in accordance with higher overall SWE. Evidence for surface-based photochemical losses of $\mathrm{Hg}$ are lower concentrations of $\mathrm{Hg}$ in upper snowpack layers (Fig. 6). Declines in $\mathrm{Hg}$ concentrations between cumulative wet deposition and integrated snowpack content were mainly driven by $\mathrm{DHg}$, with up to 4.5 times lower concentrations observed in integrated snow pit samples than volume-weighted wet deposition (Fig. 5). Aside from photochemical losses, it is possible that vertical patterns are co-determined by vertical movement and solute transport of $\mathrm{Hg}$. Previous studies have reported $\mathrm{Hg}$ pulses in runoff during snowmelt events (Schuster et al., 2008). In addition, sorption processes could lead to conversion between $\mathrm{DHg}$ and particulate $\mathrm{Hg}$ and changes snowpack $\mathrm{Hg}$ speciation. The combination of strong precipitation gradients and increased $\mathrm{THg}$ concentration with SWE leads to large spatial variability in the total snowpack $\mathrm{Hg}$ pools in mountainous areas. A previous study noted relationships between soil $\mathrm{Hg}$ content and elevation (Gunda and Scanlon, 2013), possibly attributable to precipitation gradients, while another study found that soil $\mathrm{Hg}$ storage was positively correlated with total precipitation across multiple study sites but attributed these effects to ecological processes such as increased plant productivity and carbon accumulation (Obrist et al., 2009, 2011).

Photochemical reduction and volatile re-emission of gaseous $\mathrm{Hg}$ during snowpack storage has been widely studied and is known to account for losses of up to $50 \%$ from that measured in initial deposition (Fain et al., 2007, 2011; Lalonde et al., 2002; Mann et al., 2011; Poulain et al., 2007). However, at the end of the season, we still observed substantial concentrations of $\mathrm{Hg}$ left in the snowpack (e.g., ranging from $\sim 55$ to $\sim 105 \%$ of volume-weighted wet deposition) that will be subject to melt and infiltration into the watershed. In addition to the declines of $\mathrm{DHg}$ during storage, an increase in particulate $\mathrm{Hg}$ was observed in two of the three comparisons of snow pit and wet deposition samples (Fig. 5), and it is possible that photochemical losses from snow are in part offset by gaseous dry deposition and particulate throughfall during storm free periods.

A study at the nearby Sagehen Creek, CA, watershed quantified that only $4 \%$ of total annual $\mathrm{Hg}$ wet deposition was exported from the watershed in stream water and identified soil uptake and storage as well as photochemical reemission as the major sinks of atmospherically deposited $\mathrm{Hg}$ (Fain et al., 2011). While soil uptake serves as a buffer delaying the transport of upland wet deposition to streams, sediment core analyses still showed that upland watershed contributions (i.e., through soil erosion and sediment flux) are significant contributors of $\mathrm{Hg}$ input to lakes even under relatively low watershed-to-lake-area ratios as in the Lake Tahoe Basin (extrapolated to $42 \%$ contributions when using relationships presented by Lorey and Driscoll, 1999). Snowpack-based $\mathrm{Hg}$ input to the watershed, therefore, is expected to contribute to lake water quality through erosion and sediment-based influx, albeit delayed in time and closely linked to soil $\mathrm{Hg}$ pools and mobilization.

\subsection{Basin-wide loading estimates}

Declines in Lake Tahoe water quality have been observed during the last 50 years (Sahoo et al., 2010; Schuster and 
Grismer, 2004). Specifically, Secchi depths, a measure of lake transparency, have decreased from approximately 30.5 to $21.3 \mathrm{~m}$ since the 1960s (TERC, 2011). Eutrophication from atmospheric and terrestrial nitrogen $(\mathrm{N})$ and phosphorus $(\mathrm{P})$ inputs and light scattering by particulate inputs are the main causes of this decline (Jassby et al., 2003; Swift et al., 2006). Most previous studies in the Lake Tahoe Basin have focused on direct atmospheric deposition to the lake surface (Dolislager et al., 2012; NADP, 2012), and little information is available on snowpack-based loading for the surrounding upland watershed. The surrounding land surface covers $814 \mathrm{~km}^{2}$ of the $1310 \mathrm{~km}^{2}$ Lake Tahoe watershed. Direct atmospheric inputs to the lake surface are estimated to contribute 55 and $15 \%$ of total $\mathrm{N}$ and P, respectively (TERC, 2011). Stream monitoring data show that, upon snowmelt, Lake Tahoe receives large pulses of $\mathrm{N}$ and P (Goldman et al., 1989; Hatch et al., 1999), which together control algal production within the basin's aquatic ecosystems contributing to the decline in clarity in Lake Tahoe during the last 50 years (Dolislager et al., 2006). Although much of snowpack-based chemical loads may not directly enter Lake Tahoe upon melt, snowpack loads are important for terrestrial chemical budgets. For example, nutrient-rich O-horizon runoff - measuring as high as $87.2 \mathrm{mg} \mathrm{L}^{-1} \mathrm{NH}_{4}$ $\mathrm{N}, 95.4 \mathrm{mg} \mathrm{L}^{-1} \mathrm{NO}_{3}-\mathrm{N}$, and $24.4 \mathrm{mg} \mathrm{L}^{-1} \mathrm{PO}_{4}-\mathrm{P}$ - has been observed in Lake Tahoe forests during snowmelt events due to leaching from the forest litter layer (Miller et al., 2005). In order to relate peak snowpack nutrient and pollutant loading to previous terrestrial and lake chemical budgets, we here estimate average peak basin-wide snowpack chemical storage using the peak SWE decadal average from 2000 to 2011 (Fig. 2a). While canopy effects on total snow accumulation are incorporated in this estimate through the SWE reconstruction model, we did not include forest canopy effects on deposition and chemical dynamics, as our snowpack measurements were limited to open, canopy-free locations. Deposition and snowpack dynamic processes in forests are known to show substantial differences compared to canopy-free locations, including increased dry deposition, throughfall deposition, or different photochemical processes (Poulain et al., 2007; Tarnay et al., 2002). In order to be able to compare different locations across the basin, we chose non-forested sites. The estimated deposition loads, therefore, are based on deposition and snowpack storage measured in canopy-free locations and could be different when effects of canopies and other forest processes are incorporated.

\subsubsection{Nitrogen}

Snowpack $\mathrm{NO}_{3}^{-}-\mathrm{N}$ loading was highly dependent on snow accumulation, but concentrations showed no significant temporal or spatial trends throughout the Lake Tahoe Basin (Table 1). To calculate basin-wide $\mathrm{NO}_{3}^{-}-\mathrm{N}$ loads, we therefore multiplied the 2-year seasonal average concentration $\left(47.1, \mu \mathrm{gL}^{-1}\right)$ by the decadal average reconstructed SWE.
Basin-wide $\mathrm{NO}_{3}^{-}-\mathrm{N}$ loading estimates (mass area ${ }^{-1}$ ) thus reflect snowpack accumulation patterns (i.e., SWE) with the highest loading occurring on the west side of the basin at high elevations, up to approximately $1 \mathrm{~kg} \mathrm{ha}^{-1}$, and decreasing toward the east and with lower elevations due to lower SWE accumulation. Average annual snowpack $\mathrm{NO}_{3}^{-}$-N storage for the Lake Tahoe Basin is estimated to be $28.7 \mathrm{t}$.

Unlike $\mathrm{NO}_{3}^{-}-\mathrm{N}$, snowpack TAN loading in the Lake Tahoe Basin showed strong spatial and temporal trends. Late season deposition effectively doubled snowpack TAN concentrations, with significantly higher concentrations on the west side of the basin than the east side (Table 1). Due to these relationships, we applied the March and April (peak SWE generally occurs during March and April in the Lake Tahoe Basin) average snowpack TAN concentration from the east and west basin sites to the reconstructed SWE data (western sites: $57.9 \mu \mathrm{gL}^{-1}$, eastern sites: $41.6 \mu \mathrm{gL}^{-1}$ ) to scale up snowpack TAN loading to the whole basin. Modeled estimates, therefore, show greater TAN accumulation on the western side of the basin, with highest loading occurring at high elevations in the west (up to approximately $1.2 \mathrm{~kg} \mathrm{ha}^{-1}$ ) due to the combination of both large snow accumulation and proximity to upwind sources. Our estimate of average annual basin-wide accumulation of TAN within the basin's snowpack is $30.5 \mathrm{t}$.

Snowpack organic N concentrations throughout each sampling season were variable and showed no clear temporal or spatial trends (Table 1). Applying the average concentration of $88.7 \mu \mathrm{gL}^{-1}$ from all snowpack samples throughout both years produced an annual estimate of $54.1 \mathrm{t}$ of organic $\mathrm{N}$ stored within the basin's snowpack.

Average annual snowpack $\mathrm{N}$ storage for the Lake Tahoe watershed - calculated as the sum of $\mathrm{NO}_{3}^{-}-\mathrm{N}$, TAN, and organic $\mathrm{N}$ - totaled $113 \mathrm{t}$ (Fig. 2b). Inorganic and organic forms made up 52 and $48 \%$ of total $\mathrm{N}$, respectively. TAN and $\mathrm{NO}_{3}^{-}$$\mathrm{N}$ accounted for 27 and $25 \%$ of total snowpack N, respectively. Annual N loading estimates for Lake Tahoe (from terrestrial runoff and direct atmospheric deposition) were previously estimated to be $397 \mathrm{tyr}^{-1}$, with $218 \mathrm{tyr}^{-1}$ originating from atmospheric sources depositing directly on the lake's surface (LTTMDL, 2010). With the caveat that estimation methods differed, snowpack $\mathrm{N}$ storage estimates from our study represent approximately $28 \%$ of the lake's total $\mathrm{N}$ budget. Comparing our estimates to the $179 \mathrm{t}$ of $\mathrm{N}$ that originates from runoff and terrestrial sources, annual snowpack $\mathrm{N}$ storage would replenish approximately $63 \%$ of this flux.

\subsubsection{Phosphorus}

Snowpack P accumulation in the Lake Tahoe Basin was strongly related to proximity to urban sources, as well as transport along the dominant westerly winds throughout the basin. This dependence caused the highest $P$ concentration in the snowpack to occur in developed areas and higher concentrations across east basin sites than remote west basin sites 
(Table 1). Applying different $P$ concentrations based on degree of urbanization (see Sect. 2.5), highest $\mathrm{P}$ loading (up to approximately $0.4 \mathrm{kgha}^{-1}$ ) therefore occurs at high elevations with significant impacts of urban emissions (i.e., northeastern and southern locations influenced by Incline Village, NV, and South Lake Tahoe, CA). The basin-wide average TP storage estimated during this study of $0.11 \mathrm{~kg} \mathrm{ha}^{-1}$ is more than double the average snowpack storage reported for the Emerald Lake Watershed $\left(0.04 \mathrm{kgha}^{-1}\right.$; Sickman et al., 2003) and reflects increased urbanization within the Tahoe Basin. Homyak et al. (2014) estimate that atmospheric deposition has contributed up to $31 \%$ of $\mathrm{P}$ accumulation and loss in soils and runoff since deglaciation of the Emerald Lake Watershed. The higher snowpack loading rates estimated during this study indicate that atmospheric deposition could be the primary supplier of excess $\mathrm{P}$ input to the Tahoe Basin.

Overall, we estimate a peak P load of approximately $9.3 \mathrm{t}$ of P stored annually in Lake Tahoe Basin snowpack (Fig. 2c). Previous pollutant loading studies for Lake Tahoe have estimated that approximately $46 \mathrm{t}$ of $\mathrm{P}$ enters the lake each year, with approximately $39 \mathrm{t}$ of the annual budget originating from land-based sources (LTTMDL, 2010). Annual snowpack TP storage estimates could therefore represent approximately $20 \%$ of total $\mathrm{P}$ input into Lake Tahoe each year.

\subsubsection{Mercury}

Similar to $\mathrm{NO}_{3}^{-}-\mathrm{N}$, snowpack THg concentrations showed little temporal or east-to-west variation (Table 1). However, $\mathrm{THg}$ concentrations were positively related to total SWE (slope: $0.00201\left[\mathrm{ng} \mathrm{L}^{-1} \mathrm{~mm}^{-1}\right]$; $p$ value: 0.016 ). Applying this relationship to reconstructed SWE data produced the following THg distribution throughout the Lake Tahoe Basin (Fig. 2d): THg loading throughout the basin followed strong elevation gradients, with the uppermost areas of the basin receiving the highest concentrations and total loading (up to approximately $125 \mathrm{mgha}^{-1}$ ) due to increased snow accumulation. Average annual snowpack $\mathrm{THg}$ concentration and loading for the Lake Tahoe watershed was $3.6 \mathrm{ng} \mathrm{L}^{-1}$ and $30 \mathrm{mg} \mathrm{ha}^{-1}$, respectively, based on the decadal SWE accumulation average of $750 \mathrm{~mm}$. We do not have any previous data on $\mathrm{Hg}$ deposition to this basin, but these values are comparable to the $3.3 \mathrm{ngL}^{-1}$ average snowpack $\mathrm{Hg}$ concentration and $13 \mathrm{mg} \mathrm{ha}^{-1}$ peak snowpack loading from the Sagehen Creek watershed in 2009, when snowpack accumulation was approximately $400 \mathrm{~mm}$ (Fain et al., 2011). The basin-wide estimate of THg stored within the annual snowpack was $1166.2 \mathrm{~g}$. Snow-based $\mathrm{Hg}$ fluxes estimated during this study fall within range of measurements (3.36$36 \mathrm{mg} \mathrm{ha}^{-1} \mathrm{yr}^{-1}$ ) taken at seven national parks throughout western North America during the Western Airborne Contaminants Assessment Project (WACAP), which found fish $\mathrm{Hg}$ levels above the human consumption threshold even at sites with relatively low $\mathrm{Hg}$ deposition (Landers et al., 2008).

\section{Conclusions}

In summary, spatial and temporal pattern analyses suggest that out-of-basin sources were important for $\mathrm{Hg}$ and TAN, while in-basin sources controlled P deposition, with the highest concentrations measured near urban areas, exceeding remote location concentrations by up to a factor of 6 . Snowpack $\mathrm{NO}_{3}^{-}-\mathrm{N}$ concentrations were relatively uniform throughout the basin, indicating out-of-basin sourced wet deposition as a primary input; however, high variability in snow pit vertical concentrations suggests additional inputs and in-snowpack transport and conversion processes. Second, increased $\mathrm{NH}_{3}$ emissions from the San Joaquin Valley and increased atmospheric vertical mixing during the onset of spring likely led to dry-deposition-based increases in snowpack TAN during March and April, effectively doubling snowpack TAN concentrations prior to melt. Third, chemical speciation showed that organic $\mathrm{N}$ in the Lake Tahoe snowpack accounted for $48 \%$ of total $\mathrm{N}$ on average, with possible microbial conversion leading to higher enhanced organic $\mathrm{N}$ levels in deeper, older snowpack. Fourth, particulate $\mathrm{Hg}$ was the dominant form of $\mathrm{Hg}$ ( $78 \%$ on average) within Tahoe snowpack, and concentrations of both $\mathrm{THg}$ and DHg increased with elevation and SWE likely due to decreased light penetration and reduced photochemical reemission in deeper snowpack. Finally, basin-wide modeling estimates indicated that Lake Tahoe Basin snowpack acts as a substantial reservoir in which atmospheric nutrients and pollutants accumulated throughout winter and spring. Estimates of basin-wide annual snowpack mass loading showed accumulation of $\mathrm{N}, \mathrm{P}$, and $\mathrm{Hg}$ yielding $113 \mathrm{t}$ of $\mathrm{N}, 9.3 \mathrm{t}$ of $\mathrm{P}$, and $1166.2 \mathrm{~g}$ of $\mathrm{Hg}$. Further research should focus on quantifying the relationship between snowmelt processes and stream and groundwater input, and address the substantial amount of organic N stored within the basin's snowpack.

Acknowledgements. Special thanks to Kevin Mitchell and Ted Tank of Homewood Ski Resort and Scott Hackley of the Tahoe Environmental Research Center for providing access for sampling, Mary Miller for running all nutrient analysis, Chris Moore for Hg laboratory support, Tracy Backes and Hal Voepel for assistance with data analysis, and Scott Kobs and Ashley Pierce for help with sample collection.

C. Pearson, R. Schumer, and D. Obrist were partially supported through grant/cooperative agreement number G11AP20092 from the United States Geological Survey (USGS). B. D. Trustman, R. Schumer, and D. Obrist were partially supported through NASA EPSCoR cooperative agreement number NNX14AN24A. Contents are solely the responsibility of the authors and do not necessarily represent the official views of the USGS or NASA. Additional funding was provided by DRI's Divisions of Atmospheric and Hydrologic Sciences.

Edited by: B. A. Bergamaschi 


\section{References}

Alexis, A., Delao, A., Garcia, C., Nystrom, M., and Rosenkranz, K.: The 2001 California Almanac of Emissions and Air Quality, California Air Resources Board, Callifornia Environmental Protection Agency, California Environmental Protection Agency, Air Resources Board, 2001.

Bales, R. C., Davis, R. E., and Stanley, D. A.: Ion elution through shallow homogeneous snow, Water Resour. Res., 25, 1869-1877, 1989

Battye, W., Aneja, V. P., and Roelle, P. A.: Evaluation and improvement of ammonia emissions inventories, Atmos. Environ., 37, 3873-3883, 2003.

Benedict, K. B., Carrico, C. M., Kreidenweis, S. M., Schichtel, B., Malm, W. C., and Collett, J. L.: A seasonal nitrogen deposition budget for Rocky Mountain National Park, Ecol. Appl., 23, 1156-1169, 2013.

Berg, N. H.: Ion elution and release from deep snowpacks in the central Sierra-Nevada, California, Water Air Soil Poll., 61, 139168, 1992.

Bowman, W. D.: Inputs and storage of nitrogen in winter snowpack in an alpine ecosystem, Arctic Alpine Res., 24, 211-215, 1992.

Brooks, P. D. and Williams, M. W.: Snowpack controls on nitrogen cycling and export in seasonally snow-covered catchments, Hydrol. Process., 13, 2177-2190, 1999.

Brooks, P. D., Williams, M., and Schmidt, S.: Microbial activity under alpine snowpacks, Niwot Ridge, Colorado, Biogeochemistry, 32, 93-113, 1996.

Brown, L. J., Taleban, V., Gharabaghi, B., and Weiss, L.: Seasonal and spatial distribution patterns of atmospheric phosphorus deposition to Lake Simcoe, ON, J. Great Lakes Res., 37, 15-25, 2011.

Bytnerowicz, A. and Fenn, M. E.: Nitrogen deposition in California forests: a review, Environ. Pollut., 92, 127-146, 1996.

CADWR (California Data Exchange Center): Snow Course Measurements, available at: http://cdec.water.ca.gov/snow/current/ snow/index.html (last access: 9 November 2014), 2014.

Cape, J. N., Tang, Y. S., van Dijk, N., Love, L., Sutton, M. A., and Palmer, S. C. F.: Concentrations of ammonia and nitrogen dioxide at roadside verges, and their contribution to nitrogen deposition, Environ. Pollut., 132, 469-478, 2004.

Cape, J. N., Cornell, S. E., Jickells, T. D., and Nemitz, E.: Organic nitrogen in the atmosphere - where does it come from? A review of sources and methods, Atmos. Res., 102, 30-48, 2011.

Clement, J. C., Robson, T. M., Guillemin, R., Saccone, P., Lochet, J., Aubert, S., and Lavorel, S.: The effects of snow-N deposition and snowmelt dynamics on soil-N cycling in marginal terraced grasslands in the French Alps, Biogeochemistry, 108, 297-315, 2012.

Clow, D. W., Ingersoll, G. P., Mast, M. A., Turk, J. T., and Campbell, D. H.: Comparison of snowpack and winter wet-deposition chemistry in the Rocky Mountains, USA: implications for winter dry deposition, Atmos. Environ., 36, 2337-2348, 2002.

Dasch, J. M. and Cadle, S. H.: Dry deposition to snow in an urban area, Water Air Soil Poll., 29, 297-308, 1986.

Dodds, W. K.: Misuse of inorganic $\mathrm{N}$ and soluble reactive $\mathrm{P}$ concentrations to indicate nutrient status of surface waters, J. N. Am. Benthol. Soc., 22, 171-181, 2003.

Dolislager, L. J., Lashgari, A., Pederson, J., and VanCuren, J.: Lake Tahoe Atmospheric Depositon Study (LTADS), Atmospheric
Processes Research Section Research Division, Air Resources Board, California Environmental Protection Agency, 2006.

Dolislager, L. J., VanCuren, R., Pederson, J. R., Lashgari, A., and McCauley, E.: A summary of the Lake Tahoe Atmospheric Deposition Study (LTADS), Atmos. Environ., 46, 618-630, 2012.

EPA: Methods for Chemical Analysis of Water and Wastes, Environmental Monitoring and Support Laboratory, U.S. Environmental Protection Agency, Cincinnati, Ohio 45468, Revised 3/1983, 1979.

EPA: Methods for the Determination of Inorganic Substances in Environmental Samples. Environmental Monitoring Systems Laboratory, U.S. Environmental Protection Agency, Cincinnati, Ohio 45268, 1993.

EPA: Method 1631, Revision E: Mercury in Water by Oxidation, Purge and Trap, and Cold Vapor Atomic Fluorescence Spectrometry, U.S. Environmental Protection Agency, Washington DC 20460, 2002.

Fain, X., Grangeon, S., Bahlmann, E., Fritsche, J., Obrist, D., Dommergue, A., Ferrari, C. P., Cairns, W., Ebinghaus, R., Barbante, C., Cescon, P., and Boutron, C.: Diurnal production of gaseous mercury in the alpine snowpack before snowmelt, J. Geophys. Res., 112, D21311, doi:10.1029/2007JD008520, 2007.

Fain, X., Obrist, D., Pierce, A., Barth, C., Gustin, M. S., and Boyle, D. P.: Whole-watershed mercury balance at Sagehen Creek, Sierra Nevada, CA, Geochim. Cosmochim. Ac., 75, 2379-2392, 2011.

Fenn, M. E., Haeuber, R., Tonnesen, G. S., Baron, J. S., GrossmanClarke, S., Hope, D., Jaffe, D. A., Copeland, S., Geiser, L., Rueth, H. M., and Sickman, J. O.: Nitrogen emissions, deposition, and monitoring in the western United States, Bioscience, 53, 391403, 2003.

Fierz, C., Armstrong, R. L., Durand, Y., Etchevers, P., Greene, E., McClung, D. M., Nishimura, K., Satyawali, P. K., and Sokratov, S. A.: The International Classification for Seasonal Snow on the Ground (ICSSG), International Association of Cryospheric Sciences, Paris, 90 pp., 2009.

Fram, M. S. and Belitz, K.: Groundwater Quality in the Tahoe and Martis Basins, California, U.S. Geological Survey Fact Sheet 2011-3143, 4 pp., 2012.

Galbavy, E. S., Anastasio, C., Lefer, B., and Hall, S.: Light penetration in the snowpack at Summit, Greenland: part 2 nitrate photolysis, Atmos. Environ., 41, 5091-5100, 2007.

Goldman, C. R., Jassby, A., and Powell, T.: Interannual fluctuations in primary productions: Meteorological forcing at two subalpine lakes, Limnol. Oceanogr., 34, 310-323, 1989.

Gunda, T. and Scanlon, T. M.: Topographical influences on the spatial distribution of soil mercury at the catchment scale, Water Air Soil Poll., 224, 1511, doi:10.1007/s11270-013-1511-7, 2013.

Halsall, C. J.: Investigating the occurrence of persistent organic pollutants (POPs) in the arctic: their atmospheric behaviour and interaction with the seasonal snow pack, Environ. Pollut., 128, 163-175, 2004.

Harrington, R. and Bales, R. C.: Interannual, seasonal, and spatial patterns of meltwater and solute fluxes in a seasonal snowpack, Water Resour. Res., 34, 823-831, 1998.

Hatch, L. K., Reuter, J. E., and Goldman, C. R.: Daily phosphorus variation in a mountain stream, Water Resour. Res., 35, 37833791, 1999. 
Homyak, P. M., Sickman, J. O., and Melack, J. M.: Pools, transformations, and sources of $\mathrm{P}$ in high-elevation soils: implications for nutrient transfer to Sierra Nevada lakes, Geoderma, 217-218, 65-73, 2014.

Ingersoll, G. P., Mast, M. A., Campbell, D. H., Clow, D. W., Nanus, L., and Turk, J. T.: Trends in snowpack chemistry and comparison to National Atmospheric Deposition Program results for the Rocky Mountains, US, 1993-2004, Atmos. Environ., 42, 60986113, 2008.

Jacobi, H. W. and Hilker, B.: A mechanism for the photochemical transformation of nitrate in snow, J. Photoch. Photobio. A, 185, 371-382, 2007.

Jassby, A. D., Reuter, J. E., Axler, R. P., Goldman, C. R., and Hackley, S. H.: Atmospheric deposition of nitrogen and phosphorus in the annual nutrient load of Lake Tahoe (California Nevada), Water Resour. Res., 30, 2207-2216, 1994.

Jassby, A. D., Reuter, J. E., and Goldman, C. R.: Determining longterm water quality change in the presence of climate variability: Lake Tahoe (USA), Can. J. Fish. Aquat. Sci., 60, 1452-1461, 2003.

Johnson, D. W., Susfalk, R. B., and Dahlgren, R. A.: Nutrient fluxes in forests of the eastern Sierra Nevada mountains, United States of America, Global Biogeochem. Cy., 11, 673-681, 1997.

Jones, H. G.: The ecology of snow-covered systems: a brief overview of nutrient cycling and life in the cold, Hydrol. Process., 13, 2135-2147, 1999.

King, M. D. and Simpson, W. R.: Extinction of UV radiation in Arctic snow at Alert, Canada $\left(82^{\circ} \mathrm{N}\right)$, J. Geophys. Res., 106, 1249912507, doi:10.1029/2001JD900006, 2001.

Kirchner, M., Jakobi, G., Feicht, E., Bernhardt, M., and Fischer, A.: Elevated $\mathrm{NH}_{3}$ and $\mathrm{NO}_{2}$ air concentrations and nitrogen deposition rates in the vicinity of a highway in southern Bavaria, Atmos. Environ., 39, 4531-4542, 2005.

Kuhn, M.: The nutrient cycle through snow and ice, a review, Aquat. Sci., 63, 150-167, 2001.

Lalonde, J. D., Poulain, A. J., and Amyot, M.: The role of mercury redox reactions in snow on snow-to-air mercury transfer, Environ. Sci. Technol., 36, 174-178, 2002.

Landers, D. H., Simonich, S. L., Jaffe, D. A., Geiser, L. H., Campbell, D. H., Schwindt, A. R., Schreck, C. B., Kent, M. L., Hafner, W. D., Taylor, H. E., Hageman, K. J., Usenko, S., L. K., Ackerman, J. E. S., Rose, N. L., Blett, T. F., and Erway, M. M.: The Fate, Transport, and Ecological Impacts of Airborne Contaminants in Western Nation Parks (USA), EPA/600/R-07/138, US Environmental Protection Agency, Office of Research and Development, NHEERL, Western Ecology Division, Corvallis, Oregon, 2008.

Larose, C., Dommergue, A., and Vogel, T. M.: Microbial nitrogen cycling in Arctic snowpacks, Environ. Res. Lett., 8, 035004, doi:10.1088/1748-9326/8/3/035004, 2013.

Lorey, P. and Driscoll, C. T.: Historical trends of mercury deposition in Adirondack lakes, Environ. Sci. Technol., 33, 718-722, 1999.

LTTMDL: Lake Tahoe TMDL Pollutant Reduction Opportunity Report, California Water Boards, Nevada Division of Environmental Protection, Incline Village, NV, USA, 2008.

LTTMDL: Lake Tahoe Total Maximum Daily Load Report 2010, Nevada Division of Environmental Protection, Incline Village, NV, USA, 2010.
Mann, E., Meyer, T., Mitchell, C. P. J., and Wania, F.: Mercury fate in ageing and melting snow: development and testing of a controlled laboratory system, J. Environ. Monitor., 13, 2695-2702, 2011.

McDaniel, M. R.: Semivolatile Organic Compounds in Snowmobile Emissions and in the Snowpack and Surface Water in Blackwood Canyon, Lake Tahoe, CA, 3566275, PhD thesis, University of Nevada, Reno, Ann Arbor, 137 pp., 2013.

Melack, J. M. and Stoddard, J. L.: Sierra Nevada in: Acidic Deposition and Aquatic Ecosystems: Regional Case Studies, edited by: Charles, D. F., Springer-Verlag, New York, 503-530, 1991.

Miller, W. W., Johnson, D. W., Denton, C., Verburg, P. S. J., Dana, G. L., and Walker, R. F.: Inconspicuous nutrient laden surface runoff from mature forest Sierran watersheds, Water Air Soil Poll., 163, 3-17, 2005.

Morales-Baquero, R., Pulido-Villena, E., and Reche, I.: Atmospheric inputs of phosphorus and nitrogen to the southwest Mediterranean region: biogeochemical responses of high mountain lakes, Limnol. Oceanogr., 51, 830-837, 2006.

NADP: National Atmospheric Deposition Program (NADP), National Trends Network, Champaign, IL, USA, 2012.

Neff, J., Holland, E., Dentener, F., McDowell, W., and Russell, K.: The origin, composition and rates of organic nitrogen deposition: a missing piece of the nitrogen cycle?, Biogeochemistry, 57-58, 99-136, 2002.

NRCS: Snow Telemetry (SNOTEL) and Snow Course Data and Products, available at: http://www.wcc.nrcs.usda.gov/snow/, last access: 9 November 2014, 2013.

Obrist, D., Johnson, D. W., and Lindberg, S. E.: Mercury concentrations and pools in four Sierra Nevada forest sites, and relationships to organic carbon and nitrogen, Biogeosciences, 6, 765777, doi:10.5194/bg-6-765-2009, 2009.

Obrist, D., Johnson, D. W., Lindberg, S. E., Luo, Y., Hararuk, O., Bracho, R., Battles, J. J., Dail, D. B., Edmonds, R. L., Monson, R. K., Ollinger, S. V., Pallardy, S. G., Pregitzer, K. S., and Todd, D. E.: Mercury distribution across 14 US forests. Part I: Spatial patterns of concentrations in biomass, litter, and soils, Environ. Sci. Technol., 45, 3974-3981, 2011.

O'Hara, B. F., Kaplan, M. L., and Underwood, S. J.: Synoptic climatological analyses of extreme snowfalls in the Sierra Nevada, Weather Forecast., 24, 1610-1624, 2009.

Painter, T. H., Rittger, K., McKenzie, C., Slaughter, P., Davis, R. E., and Dozier, J.: Retrieval of subpixel snow covered area, grain size, and albedo from MODIS, Remote Sens. Environ., 113, 868879, 2009.

Poissant, L. and Pilote, M.: Mercury concentrations in single event precipitation in southern Quebec, Sci. Total Environ., 213, 6572, 1998.

Poulain, A. J., Roy, V., and Amyot, M.: Influence of temperate mixed and deciduous tree covers on $\mathrm{Hg}$ concentrations and photoredox transformations in snow, Geochim. Cosmochim. Ac., 71, 2448-2462, 2007.

Raison, R. J., Khanna, P. K., and Woods, P. V.: Mechanisms of element transfer to the atmosphere during vegetation fires, Can. J. Forest Res., 15, 132-140, 1985.

Rittger, K.: Spatial Estimates of Snow Water Equivalent in the Sierra Nevada, PhD thesis, Unversity of California, Santa Barbara, 225 pp., 2012. 
Rittger, K., Kahl, A., and Dozier, J.: Topographic Distribution of Snow Water Equivalent in the Sierra Nevada, Proceedings of the 79th Annual Western Snow Conference, Stateline, NV, 37-46, 2011.

Rittger, K., Painter, T. H., and Dozier, J.: Assessment of methods for mapping snow cover from MODIS, Adv. Water Resour., 51, 367-380, 2013.

Rohrbough, J. A., Davis, D. R., and Bales, R. C.: Spatial variability of snow chemistry in an alpine snowpack, southern Wyoming, Water Resour. Res., 39, 1190, doi:10.1029/2003WR002067, 2003.

Rothlisberger, R., Hutterli, M. A., Wolff, E. W., Mulvaney, R., Fischer, H., Bigler, M., Goto-Azuma, K., Hansson, M. E., Ruth, U., Siggaard-Andersen, M. L., and Steffensen, J. P.: Nitrate in Greenland and Antarctic ice cores: a detailed description of postdepositional processes, in: Annals of Glaciology, Vol. 35, Annals of Glaciology-Series, edited by: Wolff, E. W., Int. Glaciological Soc., Cambridge, 206-216, 2002.

Sahoo, G. B., Schladow, S. G., and Reuter, J. E.: Effect of sediment and nutrient loading on Lake Tahoe optical conditions and restoration opportunities using a newly developed lake clarity model, Water Resour. Res., 46, W10505, doi:10.1029/2009WR008447, 2010.

Schroeder, W. H. and Munthe, J.: Atmospheric mercury - an overview, Atmos. Environ., 32, 809-822, 1998.

Schuster, P. F., Shanley, J. B., Marvin-Dipasquale, M., Reddy, M. M., Aiken, G. R., Roth, D. A., Taylor, H. E., Krabbenhoft, D. P., and DeWild, J. F.: Mercury and Organic Carbon Dynamics During Runoff Episodes from a Northeastern USA Watershed, Water Air Soil Poll., 187, 89-108, 2008.

Schuster, S. and Grismer, M. E.: Evaluation of water quality projects in the Lake Tahoe basin, Environ. Monit. Assess., 90, 225-242, 2004.

Sickman, J. O., Leydecker, A., and Melack, J. M.: Nitrogen mass balances and abiotic controls on $\mathrm{N}$ retention and yield in highelevation catchments of the Sierra Nevada, California, United States, Water Resour. Res., 37, 1445-1461, 2001.

Sickman, J. O., Melack, J. M., and Clow, D. W.: Evidence for nutrient enrichment of high-elevation lakes in the Sierra Nevada, California, Limnol. Oceanogr., 48, 1885-1892, 2003.

Stottlemyer, R. and Rutkowski, D.: Multiyear trends in snowpack ion accumulation and loss, northern Michigan, Water Resour. Res., 26, 721-737, 1990.

Swift, T. J., Perez-Losada, J., Schladow, S. G., Reuter, J. E., Jassby, A. D., and Goldman, C. R.: Water clarity modeling in Lake Tahoe: linking suspended matter characteristics to Secchi depth, Aquat. Sci., 68, 1-15, 2006.

Tarnay, L. W., Gertler, A., and Taylor, G. E.: The use of inferential models for estimating nitric acid vapor deposition to semi-arid coniferous forests, Atmos. Environ., 36, 3277-3287, 2002.
TERC: State of the Lake Report 2011, UC Davis Tahoe Environmental Reserach Center, Incline Village, NV, USA, 2011.

Tranter, M., Brimblecombe, P., Davies, T. D., Vincent, C. E., Abrahams, P. W., and Blackwood, I.: The composition of snowfall, snowpack and meltwater in the Scottish highlands-evidence for preferential elution, Atmos. Environ., 20, 517-525, 1986.

Turk, J. T., Taylor, H. E., Ingersoll, G. P., Tonnessen, K. A., Clow, D. W., Mast, M. A., Campbell, D. H., and Melack, J. M.: Majorion chemistry of the Rocky Mountain snowpack, USA, Atmos. Environ., 35, 3957-3966, 2001.

USGS: Methods for the Determination of Inorganic Substances in Water and Fluvial Sediments, US Government Printing Office, Washington DC, 20402, 1985.

Vicars, W. C. and Sickman, J. O.: Mineral dust transport to the Sierra Nevada, California: Loading rates and potential source areas, J. Geophys. Res., 116, G01018, doi:10.1029/2010JG001394, 2011.

Vicars, W. C., Sickman, J. O., and Ziemann, P. J.: Atmospheric phosphorus deposition at a montane site: size distribution, effects of wildfire, and ecological implications, Atmos. Environ., 44, 2813-2821, 2010.

White, A. F., Bullen, T. D., Vivit, D. V., Schulz, M. S., and Clow, D. W.: The role of disseminated calcite in the chemical weathering of granitoid rocks, Geochim. Cosmochim. Ac., 63, 19391953, 1999.

Williams, M. W. and Melack, J. M.: Precipitation chemistry in and ionic loading to an alpine basin, Sierra-Nevada, Water Resour. Res., 27, 1563-1574, 1991a.

Williams, M. W. and Melack, J. M.: Solute chemistry of snowmelt and runoff in an alpine basin, Sierra-Nevada, Water Resour. Res., 27, 1575-1588, 1991b.

Williams, M. W., Bales, R. C., Brown, A. D., and Melack, J. M.: Fluxes and transformations of nitrogen in a high-elevation catchment, Sierra-Nevada, Biogeochemistry, 28, 1-31, 1995.

Williams, M. W., Brooks, P. D., Mosier, A., and Tonnessen, K. A.: Mineral nitrogen transformations in and under seasonal snow in a high-elevation catchment in the Rocky Mountains, United States, Water Resour. Res., 32, 3161-3171, 1996.

Williams, M. W., Hood, E., and Caine, N.: Role of organic nitrogen in the nitrogen cycle of a high-elevation catchment, Colorado Front Range, Water Resour. Res., 37, 2569-2581, 2001.

Zhang, Y. Y., Obrist, D., Zielinska, B., and Gertler, A.: Particulate emissions from different types of biomass burning, Atmos. Environ., 72, 27-35, 2013. 